\title{
Monetary Policy, User Cost and Inequality: Homeowners versus Renters
}

\author{
Neha Gupta* ${ }^{\dagger}$
}

July 20, 2021

\begin{abstract}
User costs of housing are a major part of a household's expenditure. I empirically investigate the heterogeneous impact of an unanticipated expansionary monetary policy on housing markets and household tenurial decision by exploiting the user cost of housing channel. Drawing on a Swiss household panel data and daily interest rate futures, I find that the less financially constrained households are 3.45 percentage points more likely to become homeowners in case of unexpected decrease of 100 basis points in 3-month CHF Libor. The households in the upper income quartile with pillar 3a savings benefit the most in case of an unanticipated negative monetary policy shock. The real user cost expenses of renting also benefits significantly by a decrease of on average 19\% from an unexpected expansionary monetary policy. Single family houses do not benefit from the shocks in the monetary policy. The findings highlight the importance of apartments and multifamily housing.
\end{abstract}

\footnotetext{
*neha.gupta@unisg.ch, University of St. Gallen, Switzerland.

${ }^{\dagger}$ I would like to thank Zeno Adams (University of St. Gallen), Prof. Guido Cozzi (University of St. Gallen), Maria Iordache-Bolboaca (University of St. Gallen), Prof. A.N. Banerjee (Durham University) for their valuable comments and feedbacks.
} 



\section{Introduction}

Switzerland scores high on income levels and is more income equal country compared to the other developed countries. Switzerland is also constrained by a rigid housing supply owing to landscapes, higher house prices and rents and a greater proportion of renters (Bourassa and Hoesli, 2010 [8]) protected by strict rent contracts. Moreover, the Swiss monetary policy has been constantly expansionary since a few years which has a potential effect on financial and housing markets. Moreover, Switzerland is also not affected by interventions such as Tax Relief Act 1997 in the US or the financial crisis and the renters in Switzerland enjoy a high degree of protection from the federal government. This serves as a strong ground to be able to clearly quantify the housing channel effect.

The research question contributes to the literature by empirically investigating the heterogeneous impact of an expansionary monetary policy on housing markets and household tenurial decision exploiting the 'user cost of housing channel'. User cost is an important component for a typical household's decision to either own or rent a house. User cost for homeowners is monthly cash expenses in the form of mortgage payments, maintenance costs, depreciation, imputed rents etc. Similarly, for renters this expense accounts for the monthly rents and utility costs.

Further, I also aim to quantify the income inequality channel which amplifies the impact of monetary policy transmission, as wealthy households can more easily qualify for a mortgage. By exploiting the rent reforms period the study addresses an important aspect of the Swiss housing markets. 
Literature documents several channels via which monetary policy shocks affect inequality, such as the income composition, the financial segmentation, the portfolio, the savings redistribution, the earnings heterogeneity channel (Doepke and Schneider, 2006, [15], Andrei et al., 2015 [4]) and the consumption channel (Di Maggio et al., 2017 [14]). Therefore, I contribute to the literature by exploiting the 'user cost of housing' channel, specifically in the context of Switzerland.

Drawing on a Swiss household panel data and daily interest rate futures, I use market expectations approach to construct a monetary policy shock to investigate the above claim and argue the credibility of the estimates.

On average, the estimates suggest that the rich households are 3.4 percentage points more likely to become homeowners in case of unexpected decrease in monetary policy rate. The households in the upper income quartile with pillar 3a savings benefit the most in case of an unanticipated negative monetary policy shock. The real user cost expenses of renting also benefits significantly by $19 \%$ from an expansionary monetary policy. However, the estimates for the homeowners are in contradiction with the hypothesis.

The remainder of this paper is organized as follows. In Section 1.2, I summarize the related literature. In Section 1.3, I present in detail the institutional aspects of Swiss monetary policy. In Section 1.4, I give an overview of Swiss housing markets. In Section 1.5, I describe the transmission channel of monetary policy via user cost of housing . In Section 1.6, I explain the Data. In Section 1.7, I present the identification strategy. Section 1.8 discusses the empirical findings of the affect of expansionary monetary policy on Swiss households via user cost channel. Section 1.9 concludes the paper. 


\section{Literature Review}

Income and wealth distributions and therefore, inequality has always been at the relevant front of the economic research. Tradition dates back to Pareto's iron law of inequality arguing a stable income distribution and hence an unchanged coefficient of inequality in modern industrialized economies. Studies dating back to earlier times have been carried out in light of various macroeconomic and fiscal determinants for example, Kuznets (1955)[30] sketches an inverted U shape income inequality curve as a country moves through different phases of economic growth. Studies like Bourguignon and Morrisson (1998)[9], Heathecote et al. (2010) [25] studies determinants like government spending, foreign trade openness, transfer policies and wages to explain income inequality. However, studies examining the linkage between inflation and income distribution has been comparatively fewer. Bulir and Gulde (1995)[11] finds that countries with less developed financial sectors experiences a stronger negative effect of inflation on income equality. AlMarhubi (1997) [31] argues in the opposite direction that countries with greater inequality have higher average inflation. Albanesi (2007)[2] supports the evidence that countries with greater inequality makes higher average equilibrium inflation more costly for low income households (withholding more cash) due to their weak bargaining position in the political process. Cysne et al. (2005) [13] uses shopping time rationale to formalize inflation tax and its effect on inequality. They argues higher inflation, better access to transacting technology concentrates the income more for the rich. Poor, uneducated and unskilled workers are more inflation averse simply because 
of their lack of alternative asset incomes, their inability to hedge against difficult times, inflation hurts their real buying power. This curse of inflations falls disproportionately on poor people on many dimensions like poverty rate, wages, and bottom quintile of income. Easterly (2001) [16] in an international comparison of 38 countries using polling data finds that inflation lowers the share of bottom quintile and real minimum wage of the poor. Mian et al. (2013)[32] discussing housing wealth effect states that consumption responds strongly to a decline in highly levered asset class like housing which they refer to as housing net worth shock during great recession. Such a response is heterogeneous across households. Heterogeneity comes from the net worth distribution of households. Marginal propensity to consume (MPC) for poorer households out of a dollar decline in home value is larger compared to the richer households. Such a spending is estimated for autos. Housing leverage also potentially contributes to the heterogeneity in the marginal consumption. Fuess and Zietz (2016)[21] investigates the effect of funds rate on house prices for U.S. Using quarterly data (1992-2014) for 19 Meteropolitian Statistical Areas (MSAs), they investigate the importance of local demand and supply factors as a channel to explain house prices. The authors find that the interaction of monetary policy with population growth and undevelopable land significantly explains house price variations for each MSAs. By exercising the discretionary powers, injecting money into the economy or draining out money from the economy the central banks not only functions to restore and stabilize an ailing economy but also has long-term consumption redistributive effects. The actions of central bank percolates through every layer of the economy, but such effects are not uniformly distributed. These 
effects have serious long term implications for the growth of the economy. Channels such as inflation channel, portfolio channel, wealth channel, banking channel, redestribution channel which affects real estate sector in case of a shock. Homeowners and renters are an important component of real estate sector and are directly affected by the 'user cost of housing'. Therefore, the transmission mechanism channel for any potential shocks in the economy which in this particular study is an unanticipated shock to monetary policy affecting the 'user cost of housing' is being mentioned and compared with other transmission mechanism channels in the literature review.

Various channels play a role to determine these redistributive effects at the household level. Channels such as inflation channel, portfolio channel, wealth channel, banking channel, redestribution channel affects real estate sector in case of a shock. Studies like Bhattacharya et al. (2005)[7], Palivos (2005)[33], Shi (1999)[39] illustrates how devaluation of cash balances serves as a channel for redistributive effects of monetary policy. These studies state that monetary expansion redistributes real wealth from people who hold large amounts of cash/endowments to people who hold relatively lesser amounts. Erosa and Ventura (2002)[19] however, find results contrary to the above. The real wealth is redistributed from mainly cash holding poor people to capital intensive rich people. Romer and Romer (1999)[35] argues for a number of countries, where the monetary policy is aimed at higher inflation, that macroeconomic volatility deteriorates the incomes of the poor leading to increased inequality in the long run. Economic distances between various agents and central bank also serves as a potential redistribution channel. Andrei et al. (2015)[4] shows that agents like governments and investment 
banks with the shortest economic distance, i.e. direct interaction with the central bank, benefit the most from the redistributive effects of an expansionary monetary policy.

Saiki and Frost (2014)[36] studies the impact of unconventional monetary policy of the Bank of Japan on income distribution between 2008Q4 to 2013Q3 via the portfolio channel. As of 2012 the top 20\% of Japanese households held $15.4 \%$ of their assets in stocks and bonds five times higher than the share of the second top quintile. Under Abenomics, quantitative easing (QE), i.e., unconventional monetary policy (UMP), Phase II (since September 2008) saw an increased sales of condominiums and luxury products benefiting wealthy households. Using a VAR model the authors find evidence of increased inequality via capital gains from higher asset prices. Areosa and Areosa (2006)[6], theoretically examines link between optimal monetary policy and inflation via differential financial market access of agents. They argue that welfare losses increases and interest rate variability decreases with the financial exclusion.

The asset market channel is a further important redistribution channel with serious implications on wealth. Asset purchasing program as a part of QE can have significant wealth distributional implications. In U.K. top 5\% of households held $40 \%$ of assets other than pension funds whose value was affected by QE (Bank of England, 2012). Doepke and Schneider (2006)[15] assess the impact of unanticipated inflation on nominal asset positions within households and across different sectors in post war U.S. economy. Their findings suggest that inflation induces wealth transfer from foreigners to domestic households where young, middle class households with mortgage debt benefit 
the most. Rich households had lower nominal savings and rich households held long term bonds. Both these groups lost from inflation. Schularick and Taylor (2012)[38] discusses how credit financed asset booms are more dangerous in a highly financialized economy. Many studies like Rajan (2012)[34], Kumhof et al. (2015)[28], links rising inequality to credit booms and financial crises. Coibion et al. (2014) using data on mortgage applications demonstrates the expansion of credit supply for low income households in low income inequality area. The causality runs from inequality to debt accumulation.

Owing to the great financial crisis of 2007 , the effects of monetary policy have also been of important consequences for the housing markets. Housing tenurial choice is an important variable over a household's lifetime decision and is greatly influenced not only by macro economic environment and sociocultural factors but can be directly regulated by the central bank's decisions. Iacoviello and Neri (2010)[27] examines the sources of fluctuations in U.S. housing markets and argue the importance of housing market spillovers on consumption goods rather than investments. The fluctuations in real house prices are explained by demand and technological progress in the housing sector. However the authors do not rule out the growing importance of monetary factors on housing cycle, which explains $20 \%$ of the house price changes. Greenwald et al. (2018)[3] investigates transmission mechanism of monetary factors to house prices via credit growth. A similar argument in case of U.S. housing markets was put forward by Vavra and Imbs (2015)[20]. The authors aim to establish the expansion of mortgage market driven by 1996 deregulation of the U.S. banking sector as a causation of the house price 
booms from 1994-2005. Aditya Aladangady (2017) [1]uses geographically linked micro data to identify the causal effect of house price fluctuations on consumer spending particularly, for credit constrained households. Cloyne et al., (2016) [12] examines the effect of interest rate changes on expenditure of mortgagors and outright homeowners in the United Kingdom and United States. The authors claim that the general equilibrium effect of monetary policy on income is quantitatively more important than the direct effect on cash flows.

Though the above literature on housing markets discusses the transmission of the unexpected monetary policy on the housing prices, I aim to investigate the 'user cost of housing' as a mechanism channel for unanticipated shock to monetary policy at the household level. Homeowners and renters are an important component of real estate sector and are directly affected by the 'user cost of housing' which further affects the household's tenure choices. User cost for homeowners is monthly cash expenses in the form of mortgage payments, maintenance costs, depreciation, imputed rents etc. Similarly, for renters this expense accounts for the monthly rents and utility costs. The decision to own or rent a house depends on the cheaper tenure mode, i.e., relatively cheaper user costs.

\section{Swiss Monetary Policy}

Since the onset of 2000 untill 13 June 2019, the Swiss National Bank (SNB) implemented its monetary policy by defining a target range with a bandwidth of 100 basis points (one percentage point) for the reference interest 
rate, 3 month CHF LIBOR. The three-month CHF Libor for Swiss franc investments, is the trimmed mean of the interest rates for the unsecured Swiss franc interbank loans with a three- month maturity, as reported daily by interbank market in London. The other two important monetary policy strategy pursued by the SNB are the price stability under a range of $2 \%$ and a twelve quarter conditional inflation forecast. Of the three stratgy elements, three-month Libor served as an important benchmark for credit relationships in Switzerland from 2000 to mid 2019.

SNB used various monetary policy instruments like open market operations or interest rates on sight deposits to ensure well bounded LIBOR rate within the target range. As a rule, the SNB held the LIBOR as a midpoint of the target range, as illustrated in Fig 1. The determination of three month CHF-LIBOR on the interbank market in London limited the SNB's ability to control the three-month LIBOR rate directly. Therefore, in order to indirectly exert influence on three month LIBOR, SNB a) carried out transactions on the Swiss franc money market that either provided or absorbed liquidity by means of volume or conditions of the transactions b) and/or explicitly decided the interest rate on sight deposits.

The course of monetary policy does not evolve in a vacuum. Often the policy is conducted as a response to the prevailing economic environment, to smooth fluctuations. For instance, between mid-2010 and mid-2011, Swiss banking system was exposed to excess liquidity resulting from the high level of foreign exchange transactions against Swiss francs carried out by the SNB . In response, SNB influenced the reference interest rate by means of open market operations i.e. repo transactions and issuance of SNB Bills in order 


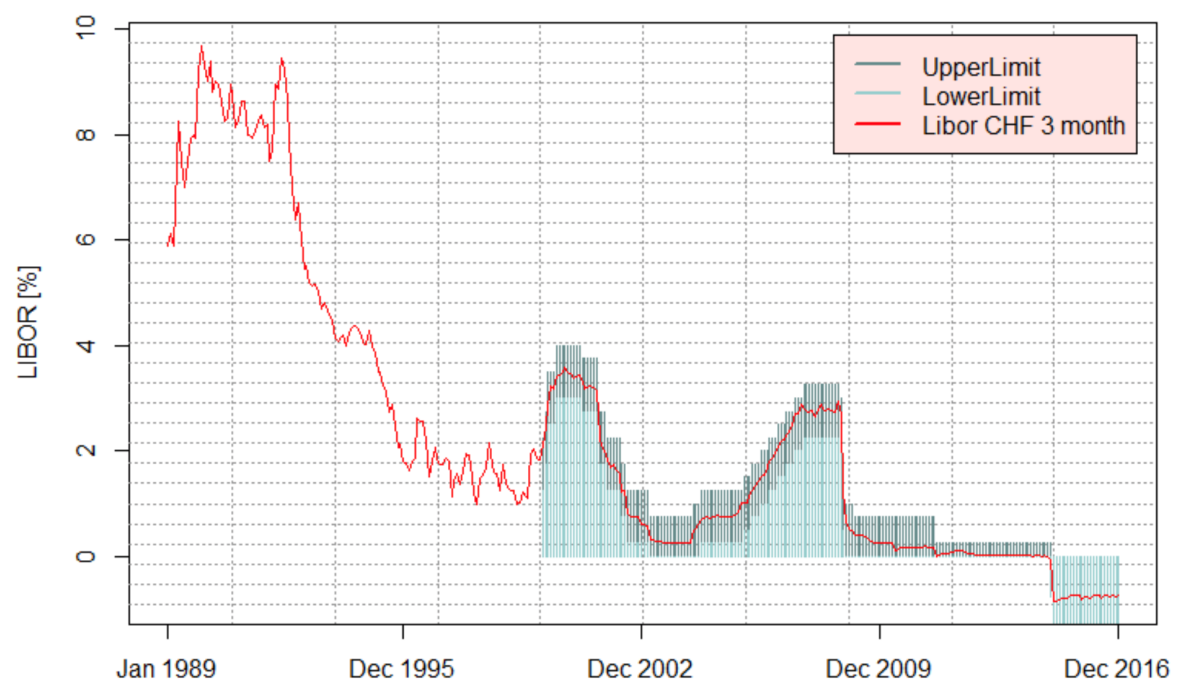

Figure 1: Monetary Policy Rate CHF-3 month Libor

Source: Author's own calculation. The figure depicts the monetary policy rate since 1989 to 2016 . The monthly data is being retreived from SNB. The colored bars denotes the CHF-3 month Libor target range.

to absorb the excess liquidity in the system.

From 6th September 2011 to 15th January 2015, SNB enforced a minimum exchange rate of CHF 1.20 per euro as the main focus of monetary policy implementation. The shield on the exchange rate was discontinued later. Simultaneously on 15th January 2015, the SNB lowered the interest rate on sight deposits to $-0.75 \%$ thereby, altering the target range for three month LIBOR downwards to $-1.25 \%$ and $-0.25 \%$. Since then the negative interest rate has been the key element of the SNB's monetary policy, the other being the intervention in the foreign exchange market.

In June 2019, target range for the three-month Swiss franc Libor was replaced by the SNB policy rate. The decision was taken due to the declining relevance of Libor in the absence of the underlying money market 
transactions. The negative interest rates also corresponds to the SNB policy rate.

\subsection{Swiss Monetary Policy: Other Long Term Interest Rates}

In Figure 2 and 3, I present the important long term interest rates in the economy from 1984-2016. All long term interest rates follow the same downward trend as the expansive 3 month CHF-LIBOR rate, since 1991. 'Nominal r' in Figure 2 is the interbank lending rate. Therefore, it is highly likely to

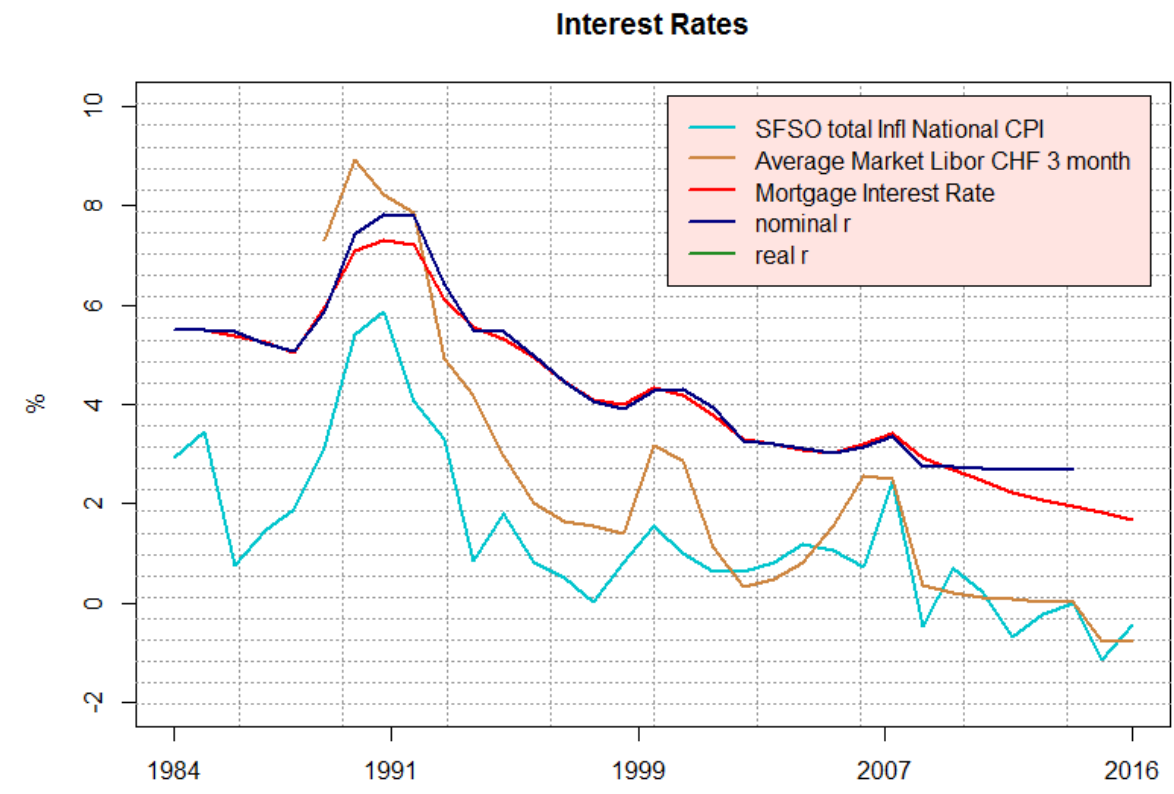

Figure 2: Long Term Interest Rates

Source: Author's own calculation. The figure depicts different interest rates from 1984-2016.

hypothesize that the direction of the affect of the shocks in the policy rate 
is highly likely to be the same for shocks in other types of long term interest rates.

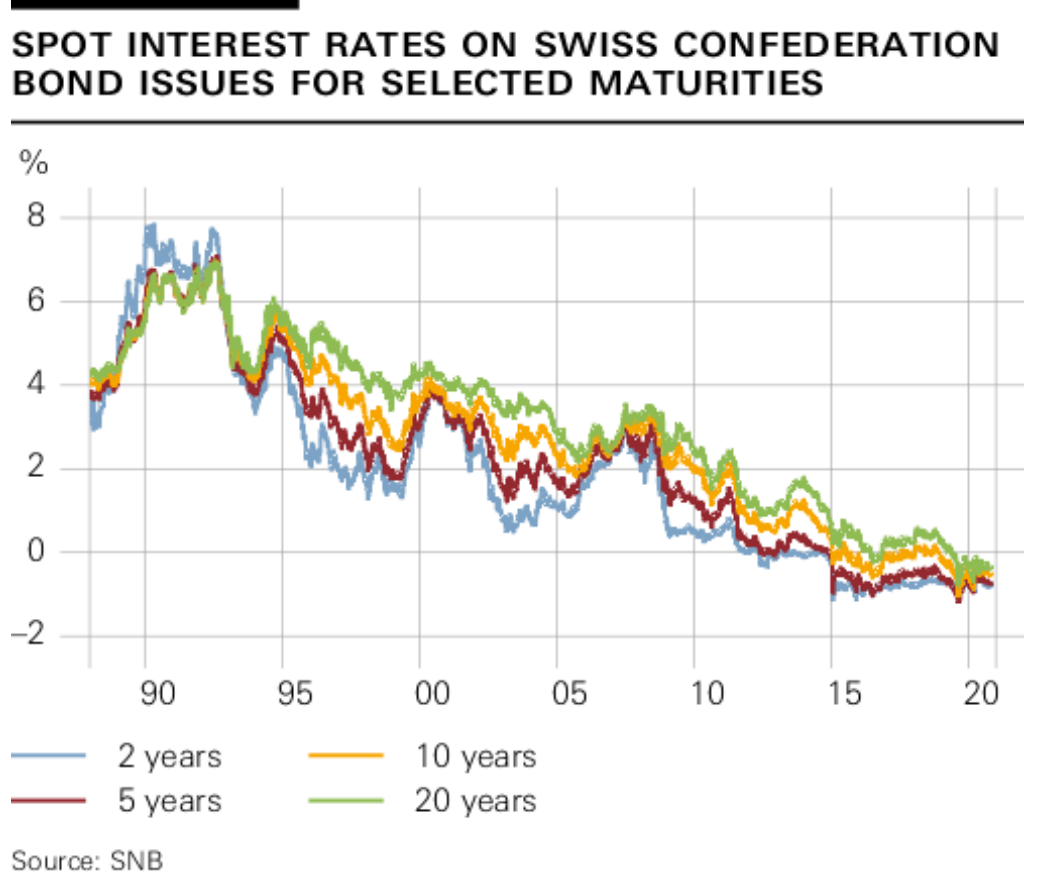

Figure 3: Spot interest rates

Moreover, in Fig 10 I demonstrate the correlation between the movements in the long term lending interest rate and tenure choice of households categorized by income. As the table depicts, the cyclical movements in the long term interest rate can potentially affect the household sector.

However, it is easy to argue that the mortgage rates are the most relevant interest rates for the housing markets and a major influencing factor for a typical household's decision to purchase a house. Therefore, in the section 8 to this chapter I provide further robustness checks by constructing similar shocks to the long term variable mortgage interest rates. The results are robust lending credibility to the main specification. 
The importance of cyclical movements of long term mortgage rates for real estate prices is depicted in the results in table 3 . The results in column (1)-(4) suggests that an expansionary monetary policy that reduces the real mortgage rate by 1 percentage point increases the middle tier real house prices by $0.6 \%$ and upper tier real prices by $1.2 \%$. The results are in line with the housing markets literature. However, the response of the housing markets with respect to shocks in the mortgage rates is also discussed in length as robustness checks in the section 8 of this chapter.

\section{Swiss Housing Markets}

Switzerland has politically autonomous administrative units comprising of 26 cantons and 2,222 municipalities ${ }^{1}$. Municipalities compete against each other in setting local tax rates, land use controls and public services, which effects the local housing markets (Hilber, 2001 [26]; Basten et al., 2014 [17]). With regards to the demography, majority (59\%) ${ }^{2}$ of the Swiss population lives in the agglomerations of the five largest cities namely Zurich, Geneva, Basel, Bern and Lausanne. Remaining population lives in the other urban areas and countryside. Strong population growth (including high immigration rate) and improved infrastructure have accelerated urban sprawl over the years.

\footnotetext{
${ }^{1}$ Office of Federal Statistics, 2018

${ }^{2}$ Swiss Federal Statistics Office, 2018
} 


\subsection{Housing Demand: Home Owning vs. Renting}

Switzerland is one of the most competitive countries with highest per capita income in the world. Yet, the home ownership rate in the country is one of the lowest amongst the European nations, at approximately $43.5 \%$ in 2017 (Swiss Federal Statistics Office, 2018).

The choices of renting and not owning a home arises from reasons of housing affordability embedded in the absolute user costs associated with homeownership, making it an expensive asset. Bourassa and Hoesli (2010)[8] uses a tenure choice model to explain economic reasons for low home ownership rates in Switzerland's five major cities. They find that the high house prices and imputed rent taxation relative to the household's income and wealth skews the choice towards renting. The taxation of imputed rents distinguishes Switzerland from most other developed countries. The competition among swiss municipalities for taxation rate indirectly affects the homeownership rate within a municipality. The homeownership rate particularly within urban areas in quite low, is the range of $10 \%^{3}$ which reflects a preferential shift in the housing demand towards renting. Preferences for homeownership are also directly affected by the mortgage rates, which are in turn affected by the monetary policy stance.

Werczberger (1997)[41] cites rents laws as one of the factors for low home ownership rate. Swiss federal law guarantees high protection to renters in Switzerland in terms of unjustified price increases and abusive evictions. Landlords are not allowed to terminate the tenancy contracts as per their

\footnotetext{
${ }^{3}$ Swiss Federal Statistics Office, 2018
} 
advantage. Moreover, the landlords can adjust rents according to two main economic indicators firstly, 'Rent Reference Index', a policy passed in 2008, which is based on the average of mortgage interest rates provided by banks in Switzerland. In case of a decline in mortgage rates tenants can ask for rent reductions. The second indicator is the Swiss consumer price index (CPI) where up to $40 \%$ of the inflation can be adjusted in the rents. In case of major renovations or increased maintenance costs, rents can be adjusted upwards.

\subsection{Housing Supply}

Glaeser et al. (2008)[23], discusses the importance of elasticity of housing supply to determine the sensitivity of house prices. Higher house prices in Switzerland directly converts from constrained topography and strict regulations on redevelopment. The heterogeneous geographic landscape of Switzerland comprising of water bodies, Alps, ruggedness, cultivable area, rocks and glaciers make a considerable proportion of the land not suited for development or urbanization. The revised Federal Law on Spatial Planning revolves around preservation of agricultural lands and natural landscapes containing urban sprawl. It strongly promotes densification, especially in areas with above-average accessibility by public transport for e.g. Zurich and Geneva. Andrews and Sanchez (2011)[5] found the supply response to price changes in Switzerland to be the lowest in their sample of 21 OECD countries. The reasons for this muted supply response includes the stringency of planning and building regulations. Cantonal construction laws addresses conflicts with planning regulations, including those that inhibit densification. Zoning is 
done at the municipal level and it is not possible for the municipality to buy the land before zoning it for settlement purposes, as buying and selling agricultural land is permitted only for farmers. In addition, smaller municipalities sets land use controls at their own discretion.

Swiss construction costs are among the highest in absolute terms and relative to both the average price of goods and the price of other fixed investment spending ${ }^{4}$. Using a stock-flow model of the Swiss housing market, Steiner (2010)[40] finds that supply-demand disequilibria can endure for extended periods of time during which prices can overshoot. The author attributes these slow dynamics in part to the slow planning process for residential construction in Switzerland. Moreover, heterogeneous building laws and codes, differentiated labor laws at the cantonal level restricts the competition in the construction sector.

\section{Monetary Policy and the User Cost Chan- nel}

\subsection{User Cost of Housing}

Tenurial choice of housing i.e., home ownership vs. renting is a decision for a consumer which is not just attributed to respective prices of a dwelling but also involves other costs. These costs constitutes the user cost of housing consumption. User cost for homeowners is monthly cash expenses in the form of mortgage payments, maintenance costs, depreciation, imputed rents

\footnotetext{
${ }^{4}$ OECD PPP database
} 
etc. Similarly, for renters this expense accounts for the monthly rents and utility costs. The decision to own or rent a house depends on the cheaper tenure mode, i.e., relatively cheaper user costs.

The costs associated varies with a country's political, administrative, economic and legal structure. Hence, the user cost function can be modeled at a country specific level.

To account for the user cost of housing in the empirical analysis, I consider the monthly accommodation expenses as a justified proxy variable for the user cost of housing as it accounts for significant proportion of the user cost. On a closer inspection in the section 'Empirical Results', the financial burden of the monthly accommodation expenses from renting are comparable to monthly accommodation expenses from owning a house. This lends further justification to use the 'housing expense' related variable from the Swiss household panel dataset.

\subsubsection{User Costs: Owner-Occupied Housing}

The transmission channel of monetary policy for home owners is more complex since it affects the user costs in several ways, some of which can have compensating effects (Brueckner, 2011)[10].

$$
U C_{h}=[(1-\tau)(i+h+m)+\delta+\varpi+g] v
$$

where, $i$ denotes the mortgage interest rates, $h$ is the property tax rate, $m$, is the maintainance costs, $\delta$, is the depreciation rate, $g$ is the capital gains defined as the annual percentage change in house values and $\varpi$ the imputed 
rent expense. $\tau$ is household specific income tax rate and $v$ is the value of house per unit of housing consumption. Therefore, equation 1 describes the user cost of per unit of owner occupied housing consumption.

In equation 1, I extend the user cost of homeownership function (Brueckner, 2011)[10] to include variables specific to Swiss housing market. Unlike the US housing markets imputed rents play a significant role for Swiss owner occupied housing and is not exempted from taxation thereby, eroding a tax subsidy for existing and potential homeowners. Additionally, Swiss homeowners are also subject to wealth tax and capital gains tax. Mortagage interest rates, property taxes and maintainance costs are tax deductible.

Thus, equation 1, describes a more complex transmission mechanism of monetary policy through house prices and their gains, apart from the direct affect of mortgage interest rates. A decline in the mortgage interest rates raises house prices, affecting wealth level and capital gains today which increases the user costs of owner occupied housing, $U C_{h}$. On the other hand, lower interest rates also affects the future price expectations which lowers the user costs. The positive effect from higher prices is therefore partly compensated by a negative effect from future price expectations with the overall interest rate effect depending on the relative strength of both the factors. I expect the first component to be more relevant since it reflects the current prices while the expectation horizon of prices is the entire life of the housing asset and therefore only partly affected by current events. Regardless of the monetary policy stance, the inclusion of imputed rents acts as a strong deterrent for potential homeowners. Imputed rent increases the user cost of owner occupied housing linearly and constitutes a significant expenditure variable. 


\subsubsection{User Costs: Rental Housing}

The transmission channel of monetary policy for tenants i.e. user costs of renting a home can be explained by equation 2 where, $v$, is the additional service charges other than rents. The user cost of renting is directly affected through the Swiss tenancy law that requires the rent change of existing contracts to be linked to a reference index (Hypothekarischer Referenzzinssatz) as shown in figure 4 .

$$
U C_{r}=\text { Rents }_{t}+v
$$

I investigate a scenario in which landlords are required by law to pass on interest rate changes in either direction to tenants directly. If landlords are forced to lower rents following an expansionary monetary policy, the user costs for the average tenant fall in a similar way as the average user cost of owning so that fewer households have incentive to become homeowners. This scenario leads to lower transitioning rates and a lower buying pressure on the housing market further depending on other factors that determine the sensitivity of price reactions. This is particularly true for regions that are densely urbanized, cities and towns placed in mountainous areas or between lakes, or other supply constrained areas. Consequently, the price dynamics of these supply inelastic regions would shift to lower and less volatile price paths compared to a scenario in which the majority of interest rate declines are not passed down to tenants. Thus, a well designed tenancy laws can provide beneficial outcomes that (1) help to mitigate the growing wealth inequality among households and (2) release some of the price pressure that has been accumulating in the Swiss real estate market. 


\subsection{Hypothesis}

\subsubsection{Hypothesis 1: An expansionary monetary policy leads to a decline in user cost of housing for both renters and home- owners.}

A decline in the interest rate influenced by the central bank has a large and immediate effect on the mortgage rate as shown in Figure 4. Everything else equal, an expansionary monetary policy decreases mortgage rates and lowers the user costs of homeowners especially for existing homeowners with Adjustable Rate Mortgages (ARM) and potential homeowners.

On the other hand, the user cost of renting a house is calculated as the monthly rent and maintenance costs that the renter has to incur. The rental expenditure in Switzerland is indexed to the mortgage rates known as 'Hypothekarischer Referenzinzatz' which in turn is affected by an expansionary monetary policy. Therefore, I hypothesize that an expansionary monetary policy decreases both the user cost of renting and owner-occupied housing.

\subsubsection{Hypothesis 2: The decline in user costs due to an expan- sionary monetary policy is relatively more for homeowners than for renters}

Equation 3 demonstrates that the rents respond asymmetrically to changes in the reference index, increasing in the same amount when the index goes up but being downward sticky when the index goes down.

$$
\Delta U C_{h}>\Delta U C_{r}
$$



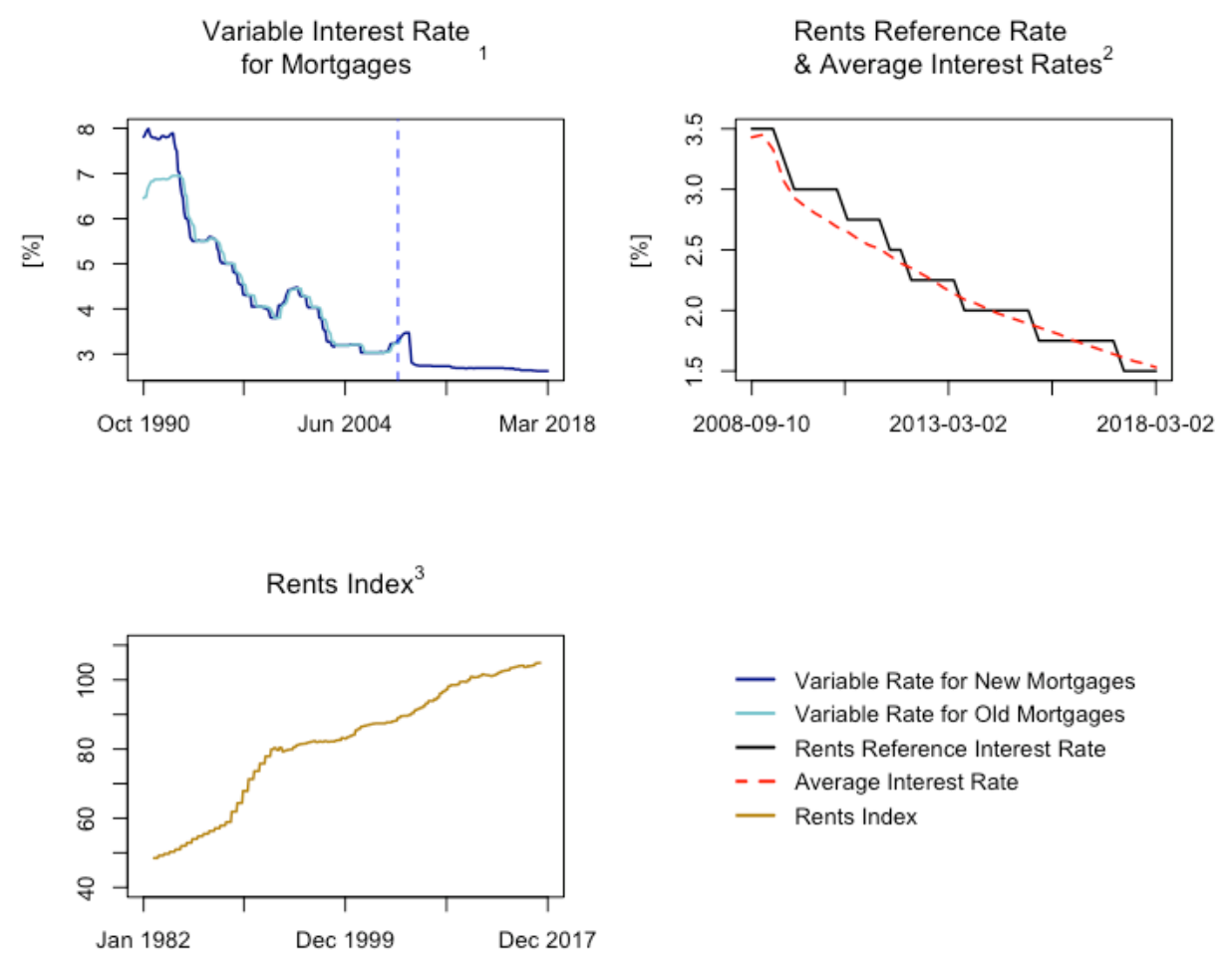

Figure 4: Reference \& Average Interest Rate

Source: Author's own calculation. The figure depicts the monthly mortgage rates, rent reference rate and rents indices. The data is being retreived from SNB. 
The reason for the limited pass-through lies in the peculiarities of the Swiss tenancy law which treats increases in the reference index as an upper bound that is usually fully utilized by landlords but decreases as a lower bound that landlords have no incentive to act upon. As a consequence, rents usually stay constant when the reference index declines. Tenants have the right to enforce lower rents but most renters do not make use of their rights, either because they prefer to remain in good standing with the landlord or because they are not aware of this possibility. Therefore, I formulate a second hypothesis to test whether the relative change in the user cost of owner occupied housing expenditure is more than the user cost of renting a house.

\subsubsection{Hypothesis 3: The relative decline in user costs and fric- tions generates larger incentives for high income renters to become homeowners.}

Following an expansionary monetary policy, households which are less financially constrained are more likely to switch to homeownership and benefit from lower user costs. In contrast, the most income constrained households have no or very small possibility to become homeowners and are at a loss due to the lack of options. Only the high-income households are able to qualify for a mortgage. As a consequence of frictions, a relatively small fraction of tenants actually transitions to homeownership. Hence, I hypothesize that an expansionary monetary policy may unintentionally amplify the already existing wealth inequality within the society. 


\section{Data}

\subsection{Monetary Policy Data}

Data for three month CHF LIBOR rate, real mortgage rates, rents reference rates from year 1999 to year 2014 were extracted from Swiss National Bank - The trading prices for Swiss futures contract on the three-month CHFLIBOR were retrieved from the Datastream. The implied policy rate was then calculated by subtracting 100 from the settlement price.

\subsection{Swiss Household Data}

Swiss Household Panel (SHP), supported by the Swiss National Science Foundation is a nationally representative, unique household longitudinal multitopic survey database for Switzerland covering various socio-economic indicators since year 1999. It is an annual panel study based on a random sample of private households in Switzerland over time, interviewing all household members mainly by telephone. The SHP interviewed a sample of 5074 households from year 1999-2004, adding a second sample of 2538 households in 2004 and an additional third sample of 4093 households in 2013. Response rates have remained high in all three samples.

The survey covers indicators of (i) household characteristics for e.g., household size, age, occupation, religion, social group, household type, endowments, commuting times, etc. (ii) housing characteristics for e.g., tenurial type, user cost, residence in which the dwelling unit is located, neighborhood characteristics, hedonics, etc. (iii) social life for e.g., frequently going out for 
dinners, social gathering, etc. (iv) financial characteristics for e.g., housing expenditures, incomes, taxes, premiums, financial situation etc. (iv) locations for e.g., if households move, canton, region, etc.

I use the data from the year 1999-2014 with a sample of 12,508 households. The location of the every household is known at administrative units of regional and cantonal level. The municipal location code of the households were obtained separately on confidentiality basis by SHP data team and then later mapped to the respective households using MS region - municipality code list from the Swiss Federal Statistical Office (SFSO). For the purpose of the study, I extract the information on household's tenure, as homeowners or renters and the associated user costs, respectively. The other variables of interest considered are civil status, nationality, education, pillar 3a savings, etc.

\subsection{Housing Markets Data}

The house prices and rents for 106 MS regions since the year 1984 are obtained from Fahrlaender Partner AG. These are the annual house price indices for single-family houses in lower, middle and higher tier range which are then matched with the vacancy rates, proportion of undevelopable land, population growth and GDP growth rate, consumer price index from SFSO. Price indices for privately owned apartments, rented building and construction costs at regional and cantonal level are also obtained from SFSO. 


\section{Identification}

\subsection{Identification: Monetary Policy Shock}

For nineteen years (approx.), three-month CHF LIBOR rate has served as an important benchmark monetary policy rate for the other interest rates e.g., confederation bonds, mortgage rates, rents reference rates, etc. thereby, influencing the Swiss economy largely. In addition, the long expansive nature of the policy rate eases the access and cost of credit, impacting the financial markets, asset prices, and the household sector. Therefore, the cyclical movements or shocks to the policy rate also percolates within these various sectors of the economy.

The daily rate for three month LIBOR for investments in Swiss francs is the trimmed mean of the interest rates on unsecured Swiss franc interbank loans with three-month maturity, reported by leading twelve banks. Thus, the daily three-month CHF LIBOR rate not only reflects the forces of demand and supply on the interbank loan market but also largely, reflects the perceptions of the leading market players at the interbank market about the SNB's future monetary policy decision. The market players anticipate in advance the decision of the SNB with regards to altering the target range for three-month CHF LIBOR. The expectations are partially embedded in the daily three-month CHF LIBOR rate to which various exchange traded financial instruments are linked, for e.g., Euro-Swiss futures contract on the three-month CHF-LIBOR.

In order to overcome the problem of endogeneity of policy rate, I follow 
the market expectations approach from the literature to construct the policy rate shock (Kuttner, 2001 [29]; Gertler and Karadi, 2014 [22]; Guerkaynak et. al., 2007 [24]). I construct the shock as below:

$$
\operatorname{shock}_{t q}=i_{l_{t q d}}-i_{f_{t q d-15}}
$$

where, in equation $4, i_{l_{t q}}$ is the midpoint rate of the target range of threemonth CHF LIBOR announced on day $d$, of quarter $q$, in year $t$. $i_{f_{t q d-15}}$ is the implied interest from the Swiss futures contract on the three-month CHF-LIBOR traded 15 days before the SNB monetary policy announcement ${ }^{5}$ $d-15$, of quarter $q$, in year $t$. The $s h o c k_{t q}$ is the shock to the monetary policy at quarter $q$, in year $t$.

The expected rate derived from the future's contract on the three-month CHF LIBOR, fifteen days before the announcement reflects the information set of the market expectation about the monetary policy rate and any deviation from the announced policy rate is the surprise component of the policy rate. Thus, the difference can be interpreted as an unanticipated shock. This surprise component is exogenous.

Figure 5, shows the time series of shocks to policy rate as calculated in equation 4 . The shock in the negative territory implies that SNB has carried out more expansionary policy as opposed to the market expectations. In general, Figure 5 is evident of the overall expansionary monetary policy stance by SNB. The larger negative shocks can also be attributed to the world events

\footnotetext{
${ }^{5}$ includes both scheduled and unscheduled announcements. Unscheduled announcements are those which are not held at the predefined regular quarterly decision events of the SNB.
} 


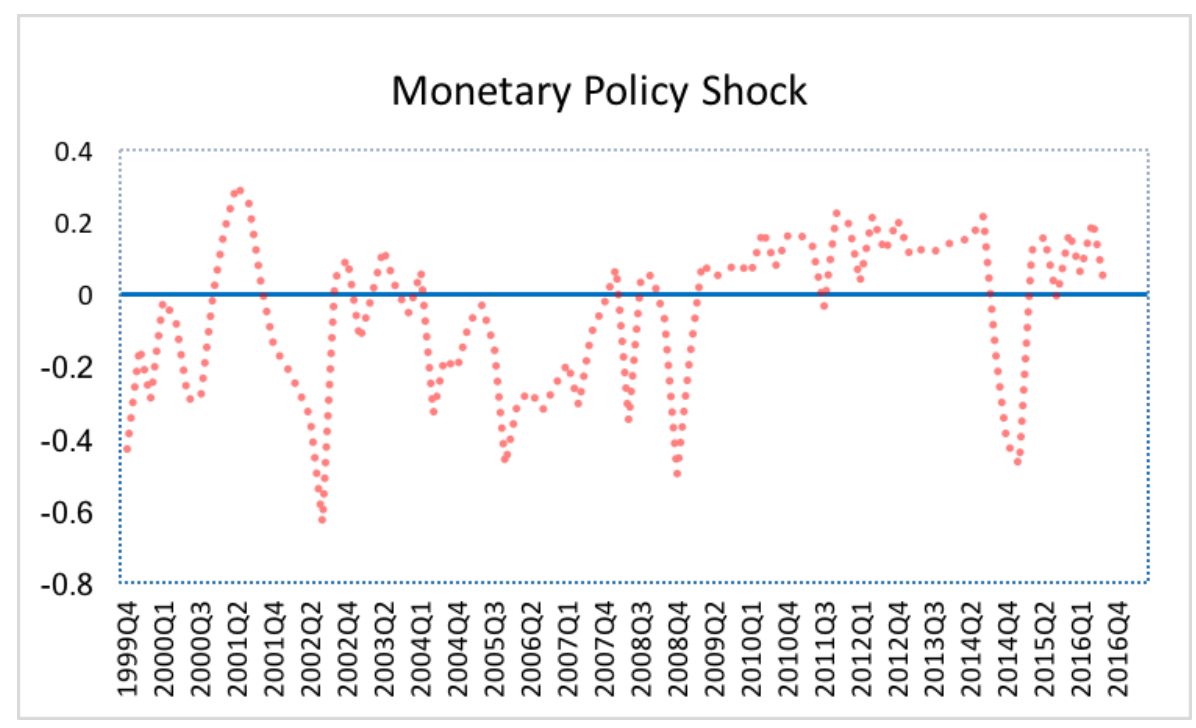

Figure 5: Monetary Policy Shock

Source: Author's own calculation. The data is being retrieved from SNB and Datastream. The figure depicts the quarterly shocks to monetary policy i.e., 3-month $\mathrm{CHF}$ LIBOR spanning a time period from 1999Q4 to 2016 Q4.

of dot-com bubble (2002), sub-prime crisis (2008) and the discontinuation of the CHF-Euro peg (2015).

\subsection{Identification: Potential Homeowners}

To identify the effect of monetary policy on homeownership, I segregate the households into initial renters, $r$, and initial homeowners, $o$ with a dummy variable $\mathrm{D}$.

$D_{r}$ for initial renting households:

$$
D_{r}= \begin{cases}1 & \text { if } d_{r}=\text { becomes a homeowner } \\ 0 & \text { if } d_{r}=\text { remains a renter }\end{cases}
$$


Similarly, $D_{o}$ for initial owner-occupied households:

$$
D_{o}= \begin{cases}1 & \text { if } d_{o}=\text { becomes a renter } \\ 0 & \text { if } d_{o}=\text { remains a homeowner }\end{cases}
$$

In both the cases, the rest of the households in the sample are dropped. Specifically once a renter household becomes a homeowner, the observations for the same household for years after the transition are dropped from the sample. The similar procedure is used for homeowners who transition to renters.

\subsection{Identification: User Costs}

To the best of the data availability I directly use a variable from SHP data called 'accommodation expenses for homeowners and renters'. These variables are identifiable via variable name h33 (homeowners) and h36 (renters). The variable give a monthly CHF rents and maintenance cost in case of tenants and monthly CHF accommodation related expenses in case of homeowners.

\section{Empirical Results}

\subsection{Descriptive Results}

In Table 1, I present summary statistics of the important variables that helps in building the identification. The SHP dataset is representative of the stylized facts about the Swiss household tenurial composition in Switzerland. 
$57 \%$ (approx.) of sampled households were initially renters at the time of their first interview. Only $14.5 \%$ of initial renters transitioned to homeowners during the sample period. Whereas, only $8.4 \%$ (approx.) of the homeowners became renters. Therefore, this ratio is suggestive of national representation of Swiss household tenurial composition.

A clear distinction between initial renters and initial homeowners is essential to the analysis in order to avoid double counting of a household and hence, the contamination of the empirical evidences.

Table 1: Descriptive Statistics: SHP

\begin{tabular}{lcc}
\hline \hline & Households (No.) & Households (\%) \\
\cline { 2 - 3 } Tenants & 7175 & 57.36 \\
Home-owners & 5038 & 40.3 \\
NA & 295 & 2.3 \\
& & 14.5 \\
Transition to Ownership & 1039 & \\
(\% of tenants) & & \\
Transition to Renting & 423 & \\
(\% of owners) & & \\
\hline Total & 12508 & \\
\hline
\end{tabular}

In Table 2 , I examine the monthly CHF differences in average monthly user cost payments for accommodation for owners and renters on the full sample over years. On average, a household exposed to the same policy rate in absolute prices spend on average CHF 1,700 per month as a homeowner, slightly more than the average expense incurred by a renter i.e. CHF 1,450 . 
This is evident of the fact that the financial burden from owning a house is comparable to renting.

However, the differences in the average monthly user cost of accommodation between homeowners and renters gradually declines over the years which gives further validity to the empirical investigation of preferential transition towards homeownership in the presence of an expansionary monetary policy via the user cost channel. The differential decline in the user costs can also be observed in terms of the real expenditure.

Housing expenses form one of the main components of monthly household expenditure. Hence, I also provide a summary statistics of ratio of housing expenses to household income in Table 2 indicating the percent of an income a typical household spends on the user cost of owning or renting a house. A typical homeowner spends about $1.6 \%$ per month of his yearly income as user cost expenses, while for a renter this percentage is slightly more, at $1.9 \%$ approximately and further increases over the years. The user cost to income ratio declines for homeowners which further increases the ratio gap between homeowners and renters, rendering renting as a more expensive alternative to homeownership.

Given the macro environment of an expansionary monetary policy, low mortgage interest rates and therefore, a lower rent reference rate, a positive trend in user cost to income ratio for renters is suggestive of only partial adjustments of housing rents to rent reference rates. These adjustments can potentially affect the housing markets via preferential shifts away from renting. This lends further credibility to the empirical investigation.

Figure 6 shows the CHF differences in user cost payments for accom- 
modation after a household transitions to ownership. On an average, the households paid CHF 308 more. The lower 2.5\% quantile is CHF 995 and the upper $97.5 \%$ quantile was CHF 1,625. Over all, households $30 \%$ had lower monthly payments once they were owners demonstrating evidences of asymmetric effects.

Table 2: Average Income and Expenditure of Household: By Tenure*

\begin{tabular}{|c|c|c|c|}
\hline & 1999-2005 & $2006-2010$ & 2011-2014 \\
\hline \multicolumn{4}{|l|}{ Real Income (Median) } \\
\hline Home-owners & 114,312 & 118,010 & 121,154 \\
\hline Tenants & 86,575 & 87,422 & 90,081 \\
\hline$\Delta$ expenses $s_{\text {owners-tenants }}$ & 27,737 & 30,587 & 31,073 \\
\hline \multicolumn{4}{|c|}{$\begin{array}{l}\text { Nominal accommodation expenses } \\
(C H F / \text { Month })\end{array}$} \\
\hline Home-owners & 1692 & 1709.5 & 1634 \\
\hline Tenants & 1333 & 1451 & 1528 \\
\hline$\Delta$ expenses ${ }_{\text {owners-tenants }}$ & 359 & 259 & 106 \\
\hline \multicolumn{4}{|c|}{ Real accommodation expenses } \\
\hline Home-owners & 1821 & 1737 & 1646 \\
\hline Tenants & 1436 & 1475 & 1539 \\
\hline$\Delta$ expenses $s_{\text {owners-tenants }}$ & 385 & 262 & 107 \\
\hline \multicolumn{4}{|c|}{ Housing expenses/Income Ratio (\%) } \\
\hline Home-owners & 1.66 & 1.60 & 1.50 \\
\hline Tenants & 1.85 & 1.97 & 2.04 \\
\hline$\Delta$ expenses ${ }_{\text {owners-tenants }}$ & -0.19 & -0.37 & -0.53 \\
\hline
\end{tabular}

*for individual years, refer to Appendix. Income is yearly gross household income 


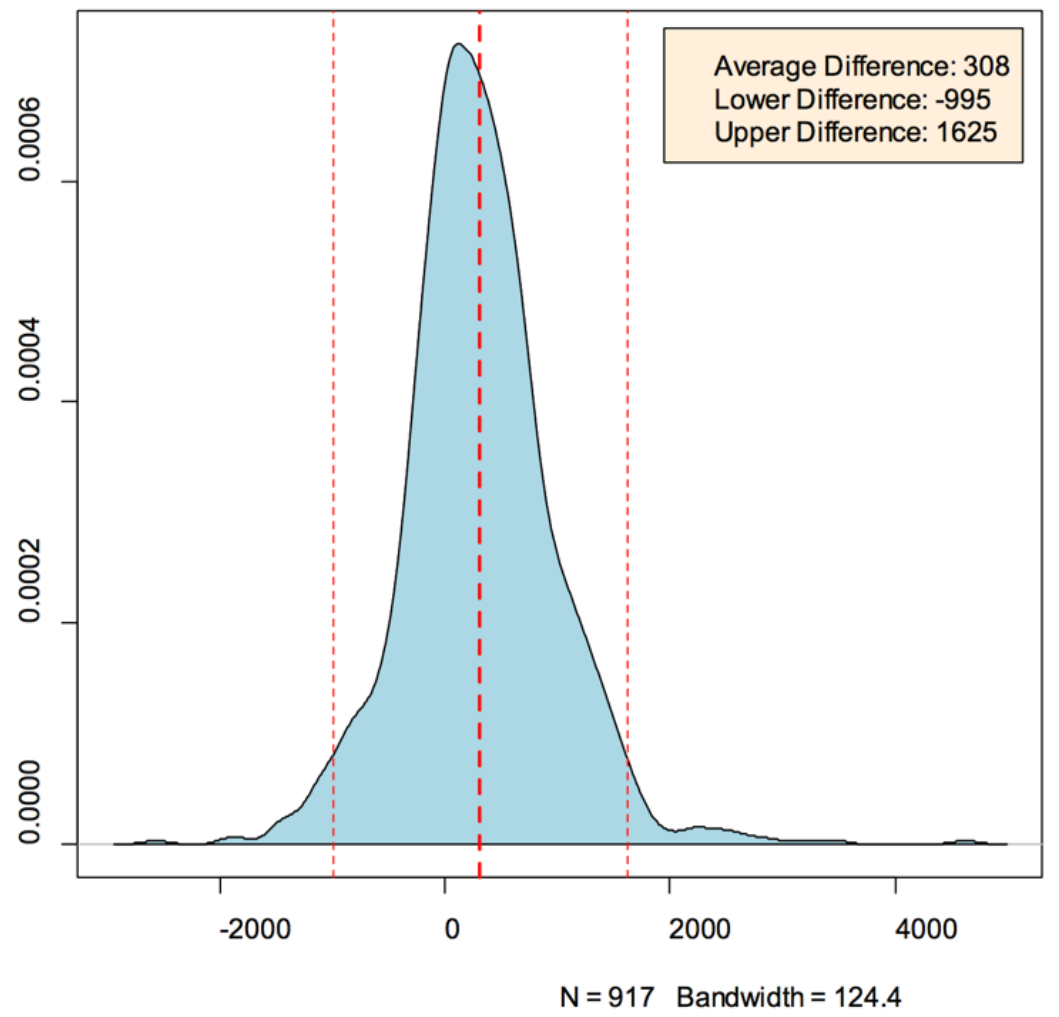

Figure 6: Distribution of Monthly Housing Expenditures

Source: Author's own calculation. The data is being retrieved from SHP and spans a time period of 1999-2014. 


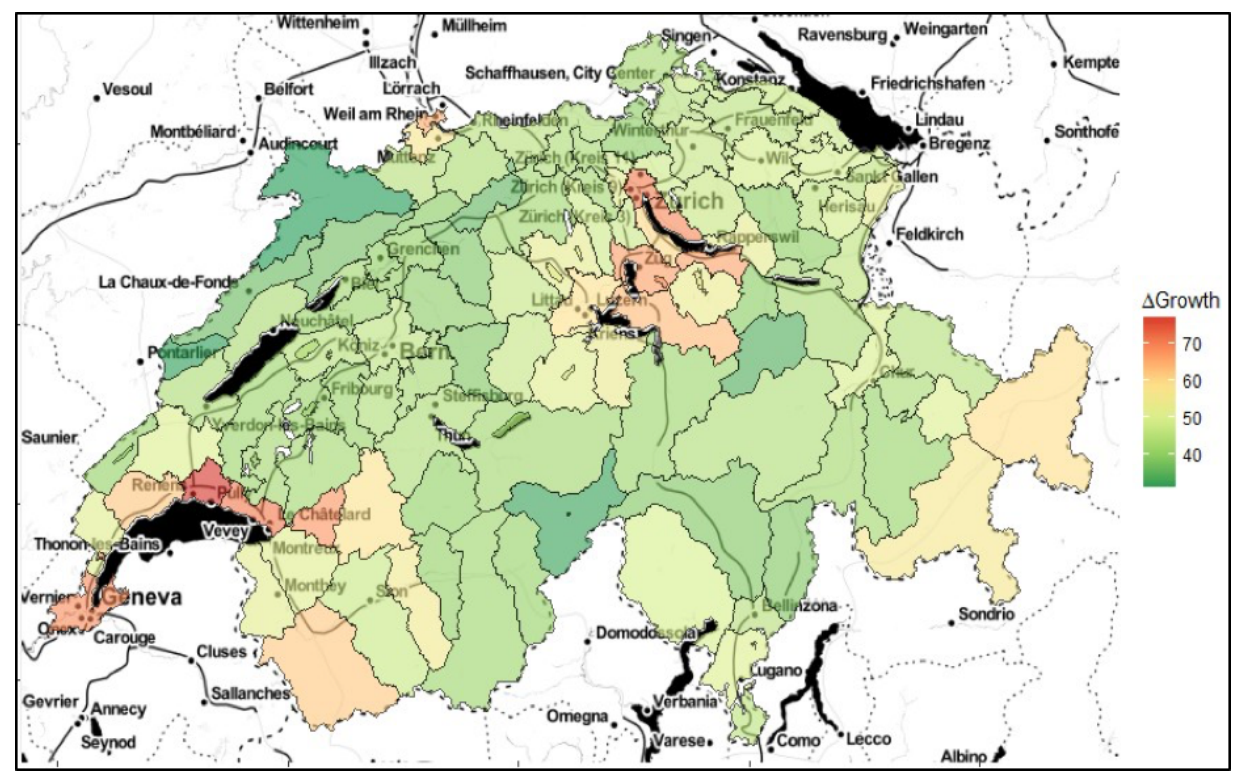

Figure 7: House Price Growth Rate

Source: Author's own calculation. The data is being retrieved from Fahrlaender Partner AG. The figure depicts the Swiss house price growth rate from 1985-2014.

In figure 7, I present the the spatial distribution of differences in annual house price growth rate from 1985 to 2014 for the low, middle, and high price category across Switzerland. The house price growth rate is calculated from house price indices $(1985=100)$. There is a substantial heterogeneity in the dynamics of house prices across regions and tiers. The gap between lower and upper tier growth rates within one region varies substantially and can be as high as $78 \%$. The growth margin appears to be highest in highly urbanized regions such as around Lake Geneva, Basel, or the Zurich-ZugLuzern metropolitan area. A few other regions which are popular tourist regions and have attracted a number of wealthy foreign individuals have also experienced an increase in the gap between lower tier and upper tier house prices. The differential margin of growth rates in tourist areas can also be 
suggestive of availability of land and other supply side measures influencing house price dynamics (Saez, 2010 [37]). Areas with constrained land have higher house prices compared to non constrained areas.

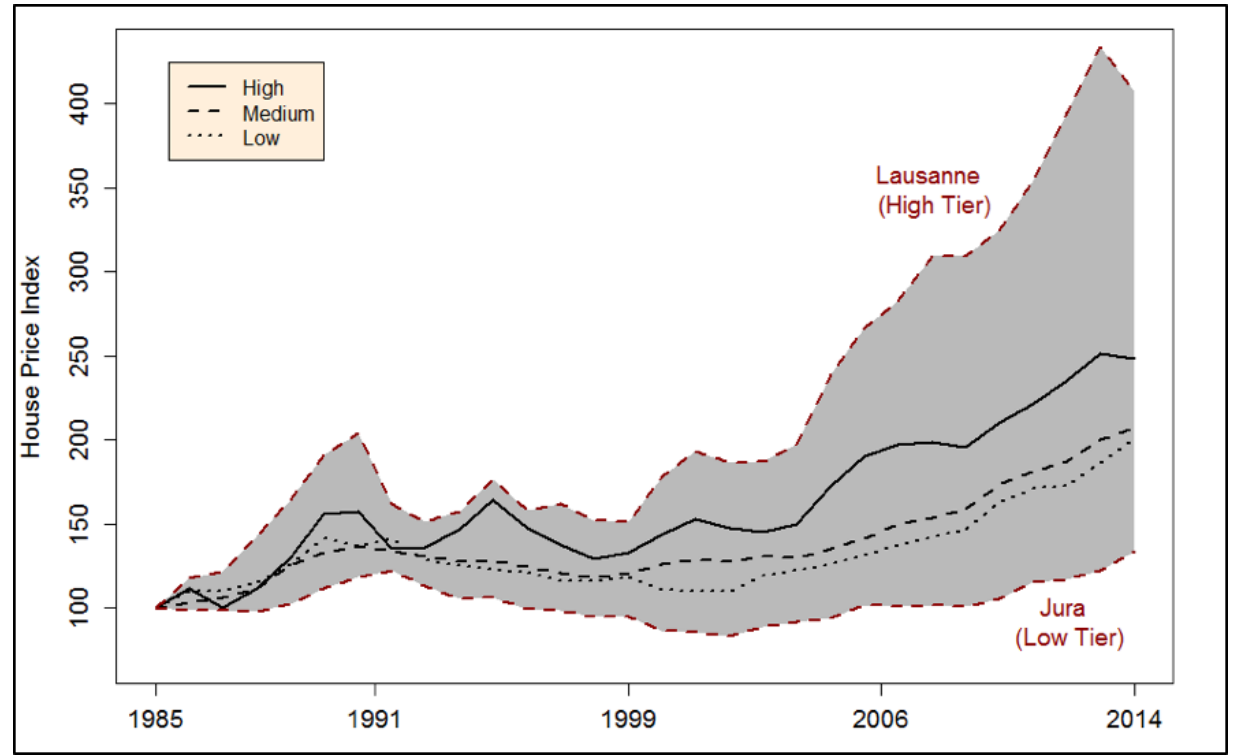

Figure 8: House Price Distribution

Source: Author's own calculation. The data is being retrieved from Fahrlaender Partner AG. The figure depicts the Swiss house price distribution from 1985-2014.

In Figure 8, I further present that house prices belonging to the high tier category show pronounced cycles and have higher growth rates over time compared to medium or lower tier house prices. For instance, upper tier house prices (solid line) have increased by $150 \%$ since 1985 while growth rates for the medium tier (dashed line) and the lower tier (dotted line) are at $+107 \%$ and $+100 \%$, respectively. These house price indices are averaged across all $106 \mathrm{MS}$ regions. The lowest growth rates are reported for the region Jura with an increase of only $34 \%$ in nominal terms, which corresponds to a $10 \%$ negative growth in real terms. In contrast, the highest price increase 
is observed for the high tier category of Lausanne, where house prices have increased by $307 \%$ since 1985 .

\subsection{Effect of Policy Shock on Housing Markets}

I estimate the effect of the constructed policy shock variable on the housing markets precisely, to empirically examine how does an unanticipated monetary policy shock affects the house prices and housing rents. In theory, an expansionary monetary policy eases the option of homeownership which further translates in to inflated house prices and hence, rents.

Since housing markets are uniquely characterized by spatial linkages I estimate equation 7 with the spatial lag panel fixed effects model with house prices (rents) as the spatial lagged dependent variable. Equation 7 is estimated using the Maximum Likelihood (ML) estimator. The lag dependent spatial model allows to take into account spatial interactions between the dependent variables or the error terms (Elhorst, 2010 [18]). Spatial fixed effects model helps to overcome the problem of omitted variable bias while assuming the spatial effects to be fixed.

$$
y_{i t}=\rho \sum_{N}^{i=1} W_{i j} y_{i t}+X_{i t} \beta+\mu_{i}+\epsilon_{i t}
$$

Similarly, I estimate equation 8 with spatial lag panel random effects model with house prices (rents) as the spatial lagged dependent variable. The model assumes unobserved spatial effects to be uncorrelated with other explanatory variables. Spatial effects are random in nature. 


$$
y_{i t}=\rho \sum_{N}^{i=1} W_{i j} y_{i t}+X_{i t} \beta+\mu_{i}+\epsilon_{i t}
$$

Both, in equation 7 and equation $8, y_{i t}$, is the outcome variable of logarithm of tier wise real house prices (logarithm of real rents) in spatial mobility regions i.e., M.S. regions, $i=1, . ., 106$ at time $t=1991, . ., 2014$. $\rho \sum_{N}^{i=1} W_{i j} y_{i t}$, specifies the spatial interaction effect. $\rho$ is the spatial slope coefficient that explains the spatial dependence of house prices (rents) in M.S. region, $i$, on the house prices (rents) of a neighboring M.S. region, $j$. $W$, is the spatial weight matrix calculated using $\mathrm{k}=5$ nearest neighbors approach (by haversine distance). Therefore, the weight matrix allows us to account for the average price impact of the neighboring M.S. regions, $j$ and is constant over time. $X$ is a matrix of regressors variables i.e., population growth, dlpop, the vacancy rate, $v$, the real mortgage rate, $r_{m}$, constructed policy shock and the percentage of undevelopable land, udl, for all 106 M.S. regions.

In Table 3, I present the estimates of equation 7 and equation 8. Columns (1)-(8) are based on a balanced panel. Panel (A) in Table 3, shows the estimated coefficients for a spatial panel fixed effects model with M.S. region fixed effects. The spatial lag parameter $\rho$ indicates a high degree of spatial dependence on the level of M.S. regions. This is likely to be the result of the geographical proximity in combination with a well-functioning transportation network and high labour mobility. The coefficient for population growth is around 0.3 indicating that a $1 \%$ increase in population growth increases real house prices on average by $0.3 \%$. 


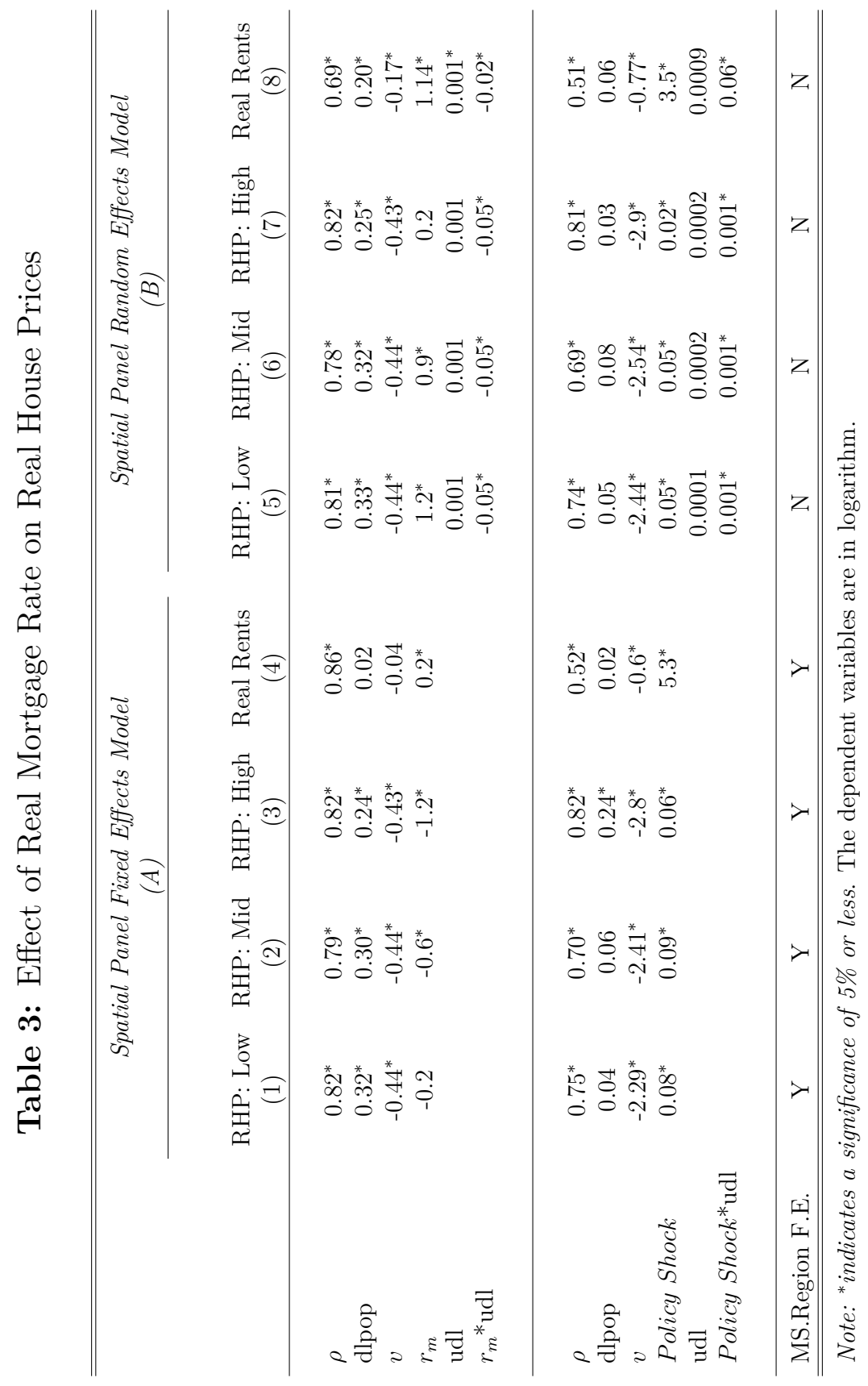


The vacancy rate, $v$, has the expected negative sign and is statistically significant. An expansionary monetary policy that reduces the real mortage rate by 1 percentage point has no effect on lower tier real house prices, but increases middle tier real house prices by $0.6 \%$ and upper tier real prices by $1.2 \%$. The effect of a lower real mortgage rate is therefore not symmetric but is much stronger for houses within the high price category. However, the constructed policy shock has an unexpected puzzling positive sign but is statistically significant. The more negative the policy shock is the more expansionary is the monetary policy stance of the SNB. Therefore, an unexpected expansionary policy is associated with decreasing house prices although the effect is negligible around $0.08 \%$. One potential explanation for this puzzle could be that even though the house prices react positively to lower mortagage rates, their reaction to expansionary policy beyond the market expectations is negligible. Glaeser et al. (2008)[23], show that the impact of demand and supply shocks affecting house prices depend on the elasticity of housing supply. In panel (B) of Table 3, I estimate a spatial panel random effects specification stated in equation 8 which includes the interaction of the real mortgage rate with the time-invariant percentage of undevelopable land, $\mathrm{udl}^{6}$, as an additional regressors. In this specification, the effect of the real mortgage rate is estimated to be initially positive but decreases with the level of undevelopable land.

Columns (4) and (8) represents the estimates of equation 7 and equation

\footnotetext{
${ }^{6} \mathrm{udl}$ is an abbreviation for undevelopable land. It is the percentage of land not suited for habitation at M.S. region level. Other variables are explained in the appendix to this chapter.
} 
8 for logarithm of real rents as the dependent variable. The statistically significant positive effect of the real mortgage rate on real rents is likely to be the result of a partial market adjustment of rents owing to the linkage of mortgage rates with rent reference rates. Further, the effect on real rents decreases with the level of undevelopable land.

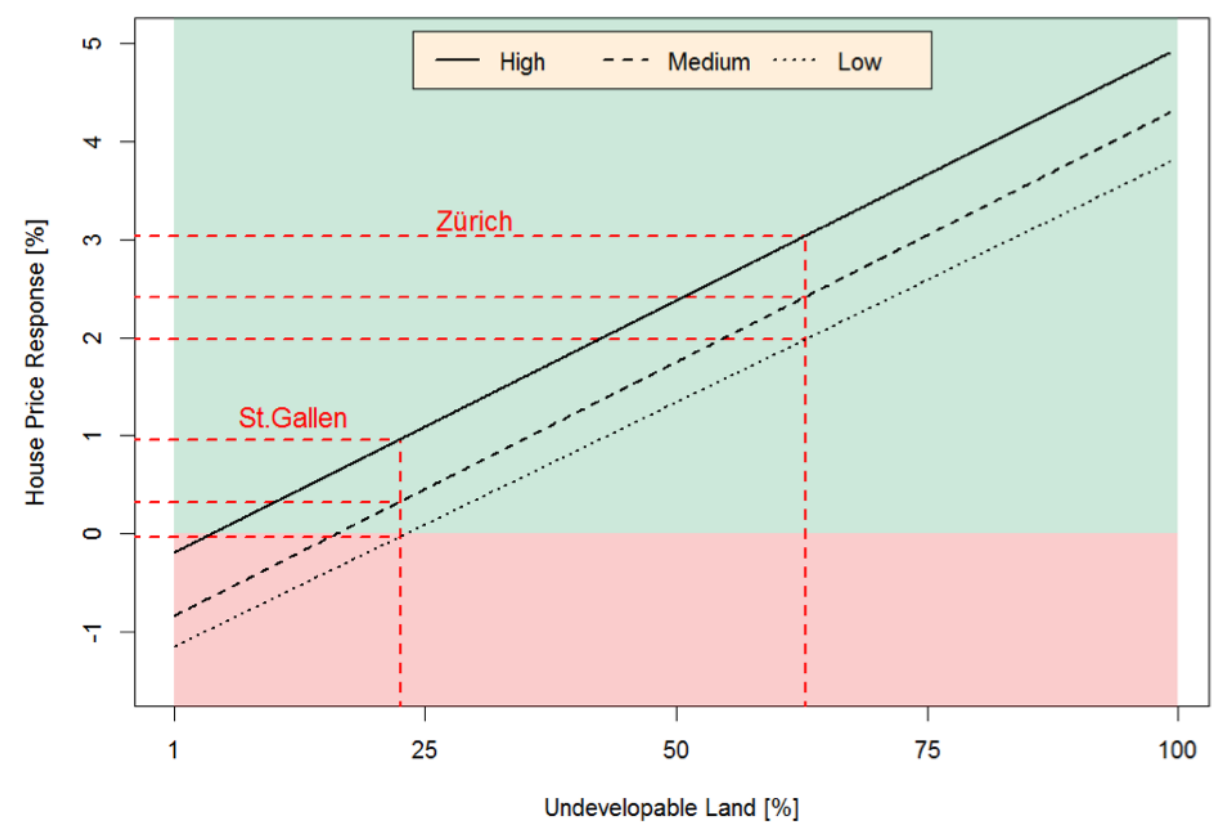

Figure 9: House price response

Source: Author's own calculation. The data is being retrieved from SFSO. The figure depicts the house price response as a function of the undevelopable land i.e., supply side factors.

To put the interaction into economic perspective, we illustrate the impact of a expansionary monetary policy (i.e. a $1 \%$ lower real interest rate) in Figure 9. The marginal effects depend on the house price tier indicated by the solid line (high price tier), the dashed line (medium tier) and the dotted line (lower tier). However, the effect is also strongly driven by the underlying 
level of undevelopable land. For instance, the region St. Gallen has $23 \%$ of its surface being undevelopable. St. Gallen can be therefore regarded as being relatively elastic in its housing supply. In this case, a $1 \%$ drop in the real interest rate has no effect on lower tier house prices but increases upper tier house prices by roughly $1 \%$. In contrast, the same expansionary policy shock in Zurich with a high level of undevelopable land i.e. $63 \%$ is substantially larger. A $1 \%$ lower real interest rate increases lower tier house prices in Zurich by $2 \%$ and upper tier house prices even by $3 \%$. Our findings in Figure 9 confirm that house prices do not respond symmetrically to changes in the monetary policy rate.

Even though there exists a possibility of spillovers between different tiers of houses. However, to measure the inter-dependence of the tier wise house prices is out of the scope of this study.

Table 4: Stationarity Test of Real House Prices

\begin{tabular}{lcccc}
\hline \hline \multicolumn{4}{c}{ Augmented Dickey Fuller Test } \\
\hline & LRHP: Low & LRHP: Mid & LRHP: High & Log Real Rents \\
\cline { 2 - 5 } DF - Value & -6.99 & -7.88 & -8.63 & -6.94 \\
Lag & 11 & 11 & 11 & 11 \\
$p-$ value & 0.01 & 0.01 & 0.01 & 0.01 \\
& & & & \\
\hline DF - Value is the Dickey-Fuller value. & The prices are in log real terms.
\end{tabular}

To check for the stationarity of the house prices, I use the Augmented Dickey Fuller Test $(\mathrm{ADF})$ on logarithmic of real house prices and rents by tiers in the Table 4. As the results show that the p-value is less than $5 \%$ level of 
significance. Therefore, the null hypothesis of logarithmic of real prices being non stationary can be rejected with confidence.

\subsection{Effect of Policy Shock on Accommodation Expenses: Hypothesis 1}

I estimate equation 9 with a linear panel fixed effects model to identify the effect of a monetary policy shock on the user cost of homeownership and renting. By empirically investigating equation 9, I aim to testify hypothesis 1. Additionally, as an outcome variable already drops the household from the sample once they have transitioned to homeownership. Therefore in the remaining sample all households that were renters have transitioned to homeownership at one point.

$$
y_{i t}=\alpha+\beta \text { policy shock }{ }_{i t}^{\prime}+c_{i}+\mu_{i t}
$$

where, $y_{i t}$, is the outcome variable logarithm of nominal user cost expenses (logarithm of real user cost expenses) for household, $i=1, \ldots, N$ at time, $t=1999, . ., 2014$. policy shock $k_{i t}^{\prime}$, is the time varying vector of constructed monetary policy shock facing a household, $i$, at time, $t$. $\alpha$, is the constant term, $c_{i}$, is the household specific effect, $\mu_{i t}$, is the idiosyncratic error term. $\beta$ is the parameter of interest.

Equation 9 is repeatedly estimated for sub sample of homeowners and renters, separately, where the outcome variable is the logarithm of nominal user cost expenses (logarithm of real user cost expenses) of homeownership and renting, respectively. In the appendix, I again present the estimates 
for equation 9 to identify the effect of a different kinds of interest rates on the user cost of home owning and renting. The explanatory variables are mortgage rates and monetary policy rate.

Unlike, equation 7 and equation 8 the outcome variable in equation 9 is the user cost of housing expenses for renters and homeowners at household level which are not spatially connected. Therefore, spatial spillovers in this case are not taken into account.

In Table 5, Panel (A), I present the estimates of equation 9 for the outcome variable logarithm of nominal user cost expenses for three different types of households. Panel (B), outcome variable is the logarithm of real user cost for three kinds of households. Columns (1)-(6) are based on an unbalanced panel. The estimates in Table 5, column (1)-(3) suggests monetary policy shock decreases the nominal user cost expenses for renters by 19 percent and is quite sizeable in economic terms. The user cost of housing decreases overall by 8.5 percent for all households in the sample and is highly statistically significant. Whereas, a 1\% (100 bps) shock to the monetary policy increases the cost for homeowners which is contrary to the hypothesis stated. These estimates provide a mix evidence in support of hypothesis 1 .

The estimates (Table 5) suggests that the benefits of expansionary policy regime are passed on to renters via rent reference rates. Hence, the evidence for hypothesis 1 is mixed which makes it further difficult to claim in favor of hypothesis 2 . 


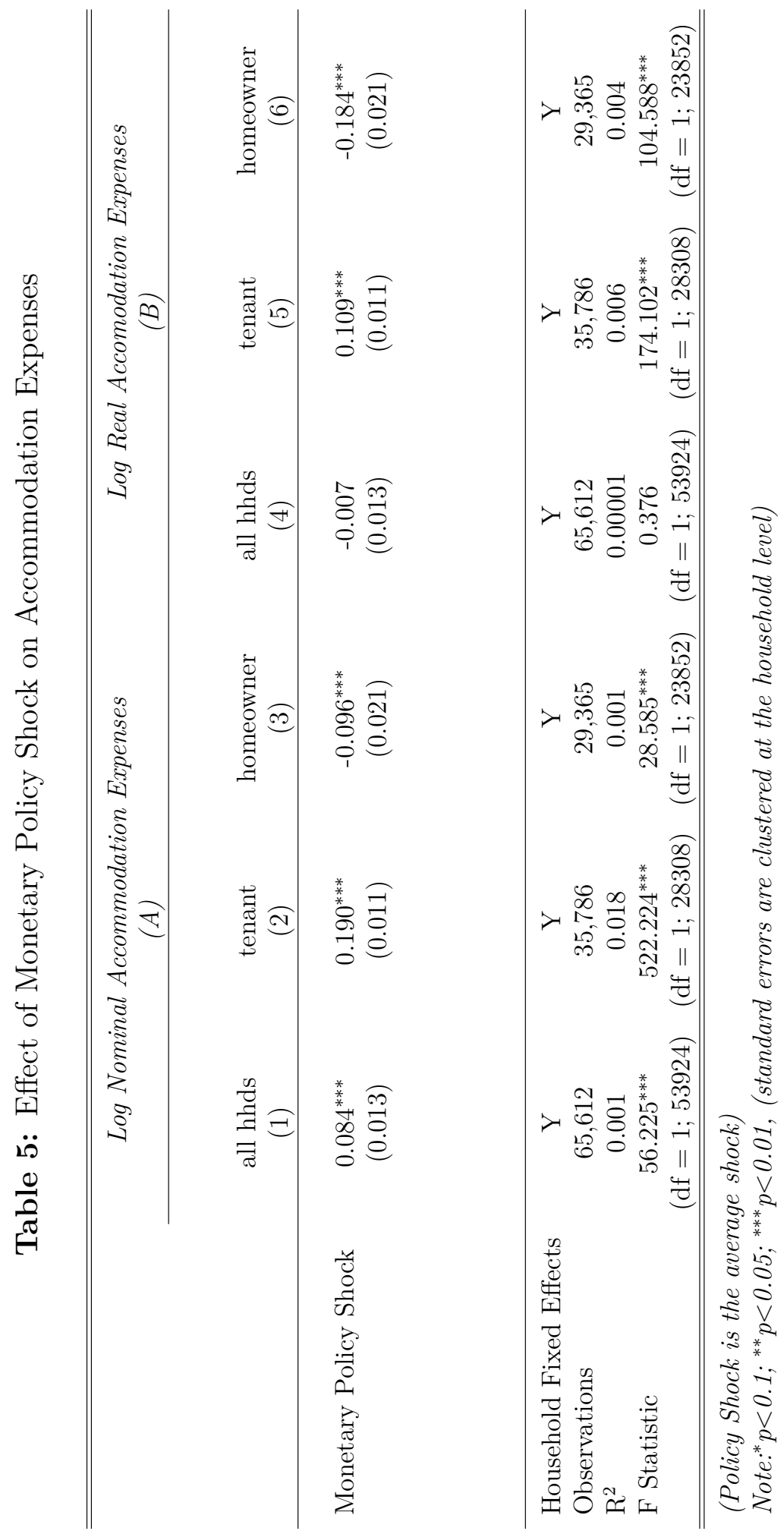




\subsection{Effect of Policy Shock on Tenure Choice: Hypoth- esis 3}

I estimate equation 10 with a linear probability model to identify the effect of a monetary policy shock on the probability of homeownership. Such an effect helps to testify the stated hypothesis 3 .

$$
\begin{aligned}
y_{i t}= & \alpha+\beta \text { policy } \text { shock }_{i t}^{\prime}+\gamma D_{i t}+\delta\left(D_{i t} * \text { policy shock }{ }_{i t}^{\prime}\right) \\
& +\phi z_{i}^{\prime}+c_{i}+r_{i}+\mu_{i t}
\end{aligned}
$$

where, $y_{i t}$, is the outcome dummy variable $=1$ for homeownership status change of a household, $i=1, \ldots, N$ at time, $t=1999, . ., 2014$ that was initially a renter in the sample. policy shock $k_{i t}^{\prime}$, is the time varying vector of constructed monetary policy shock facing a household, $i$, at time, $t$. $D_{i t}$ is the dummy variable if a household falls in the above or below median income category. $z_{i}^{\prime}$ is a vector of control variables at household level, $i$. $\alpha$, is the constant term, $c_{i}$, is the household specific effect, $r_{i}$, is the region specific effect, $\mu_{i t}$, is idiosyncratic error term. $\delta$ is the parameter of interest.

Unlike, equation 7 and equation 8 the outcome variable in equation 10 is not are spatially connected as well. Therefore, spatial spillovers in this case are also not taken into account. Additionally, as an outcome variable already drops the household from the sample once they have transitioned to homeownership. Therefore in the remaining sample all households that were renters transitioned to homeownership at one point.

In the appendix, I present robust estimates using equation 10 to identify 
the effect of a monetary policy shock on the probability of homeownership using full sample. I also test the effect of a monetary policy shock on the probability of renting.

In Table 6 , I present the estimated coefficients of equation 10 along with household and region fixed effects. Columns (1)-(3) are based on an unbalanced panel. Column (1) estimates the effect of a monetary policy shock and gross income on the probability of transitioning from being a renter to a homeowner. The impact of the policy shock on the variables occurs with a lag of at least one year. The data sample for regression results in column (2) is grouped into rich households and poor households which is demonstrated by the dummy variable Income (> q50). Rich households are assigned a value 1 and poor households as 0 . Rich households are the one whose yearly gross income (in CHF) is more than the median income (calculated to be 90,000 $\mathrm{CHF} /$ year) of all households that are initial renters in the sample. Households that are below or at median income levels are considered to be poor households. Therefore, column (2) estimates the effect of a monetary shock on the probability of transitioning from being a renter to a homeowner for a rich or poor household. The results in column (3) provides estimates with added controls.

The coefficient for lagged monetary shock (column 1) has expected negative sign and is highly statistically significant. Holding everything else constant, a negative monetary shock (expansionary monetary policy) of 1 percent (100 bps) is estimated to increase the probability of transitioning to home ownership by 2.35 percentage points for all households on average. However, the effect of a monetary shock is heterogeneous for poor and richer house- 
holds (column 2). The interaction term between lagged policy shock and income status suggests that while, both groups of households tend to benefit from an expansionary monetary policy but the effect for richer households to transition to home ownership is estimated to be much stronger at 3.45 percentage points $(1.75+1.7)$ and statistically significant.

In Table 7 , the initial renters are further grouped into quartile incomes and Table 8 provides estimates of the interaction of grouped households with 'pillar 3a savings'. Within richer household, those within the upper income quartile (Table 7) benefit the most from a negative shock with increased probability of becoming a homeowner by 5 percentage points $(1.1+3.9)$. The estimates are statistically significant and sizeable in economic terms. Figure 10 also illustrates this fact where the co-movement between interest rate and richer households transitioning to homeownership is strongly correlated than for the poor households. However, without a change in any economic conditions like a change in monetary policy, the richer households are 1.9 percentage points more probable to change their status as a homeowner relative to poor households. This effect is even stronger and statistically significant for the cohort of households in the upper income quartile at 3 percentage points (Table 7).

The estimates provide a strong support to the hypothesis 3. From the results it can be inferred that income constraints act as an important impediment for Swiss households to become homeowners. The increased access to the financial market due to expansionary monetary policy favors the least financially constrained households the most, widening the wealth inequality gap. A Swiss household is 0.6 percentage points more likely to switch 
to homeownership (Table 6), with even a higher probability of 1.1 percentage points in case the household has a married couple and a slightly lower probability of 0.8 percentage points in case the married couple have children.

Pillar 3a savings ${ }^{7}$ (Table 8) are an important financial reserve which can influence the decisions about home purchases for a household. On an average, a renting household with pillar 3a savings is 0.9 percentage points more likely to buy a house. For a richer household this probability increases by 1.4 percentage points with a total effect of 2.3 percentage points. Within the richer households with pillar 3a savings, the probability to transition to homeownership is the even stronger and statistically significant for households in the uppermost income quartile at 2.6 percentage points. Therefore, any shock to the monetary policy can have sizeable effects for household with pillar 3a savings. Holding everything else constant, an average renting household with pillar 3a savings is 3.6 percentage points more likely to transition to home ownership once exposed to a negative monetary shock of 100 bps. The effect is statistically significant.

\footnotetext{
${ }^{7} \mathrm{~A}$ pillar $3 \mathrm{a}$ investment account is a Swiss retirement savings vehicle which allows a household to both save and invest. It also allows account holders to invest part of their assets in securities like bonds, stocks or funds and are best suited to long-term investments. Pillar $3 \mathrm{a}$ investment accounts are subject to limitations on fixed maximum annual contributions which are eligible to be deducted from taxes. However, because $3 \mathrm{a}$ investment accounts involve more risk than 3a savings accounts. Account holders can earn higher returns on their assets, but there is also a risk of loss. Pillar 3a savings can also be used to purchase a home or condominium. A household has the option of early withdrawal of the pillar $3 \mathrm{a}$ funds to purchase a home (withdrawals possible every five years). Or can pledge the retirement savings and benefit from the preferential tax treatment. Just as with assets withdrawn from the pension fund, the capital paid out of pillar $3 \mathrm{a}$ is subject to tax. However, unlike with the second pillar, one does not have to pay back these early withdrawals if they sell their home.
} 
Table 6: Heterogeneous Effect of Policy Shock on Homeownership

\begin{tabular}{|c|c|c|c|}
\hline & \multicolumn{3}{|c|}{ Transitioning to Homeownership (=1) } \\
\hline & $\begin{array}{l}\mathrm{LPM} \\
(1)\end{array}$ & $\begin{array}{l}\text { LPM } \\
(2)\end{array}$ & $\begin{array}{l}\mathrm{LPM} \\
(3)\end{array}$ \\
\hline $\begin{array}{l}{ }^{1} \text { Gross Income } \\
(C H F / \text { Year })\end{array}$ & $\begin{array}{l}0.0041^{* *} \\
(0.00000)\end{array}$ & & \\
\hline $\operatorname{Income}(>\mathrm{q} 50)$ & & $\begin{array}{c}0.019^{* * *} \\
(0.001)\end{array}$ & $\begin{array}{c}0.007^{* * *} \\
(0.002)\end{array}$ \\
\hline Policy Shock $_{t-1}$ & $\begin{array}{c}-0.023^{* * *} \\
(0.003)\end{array}$ & $\begin{array}{c}-0.017^{* * *} \\
(0.003)\end{array}$ & $\begin{array}{c}-0.016^{* * *} \\
(0.003)\end{array}$ \\
\hline Policy Shock $_{t-1} *$ Income $(>\mathrm{q} 50)$ & & $\begin{array}{c}-0.017^{* * *} \\
(0.005)\end{array}$ & $\begin{array}{c}-0.018^{* * *} \\
(0.005)\end{array}$ \\
\hline $\begin{array}{l}\text { Nationality } \\
(\text { Swiss }=1)\end{array}$ & & & $\begin{array}{c}0.006^{* * *} \\
(0.002)\end{array}$ \\
\hline $\begin{array}{l}\text { Civil Status } \\
(\text { Married }=1)\end{array}$ & & & $\begin{array}{c}0.011^{* * *} \\
(0.002)\end{array}$ \\
\hline $\begin{array}{l}\text { Education } \\
\text { (in years) }\end{array}$ & & & $\begin{array}{l}0.001^{* * *} \\
(0.0003)\end{array}$ \\
\hline Age & & & $\begin{array}{l}-0.0001^{* *} \\
(0.00004)\end{array}$ \\
\hline $\begin{array}{l}\text { Family Type } \\
\text { (married with kids) }\end{array}$ & & & $\begin{array}{c}0.008^{* * *} \\
(0.003)\end{array}$ \\
\hline $\begin{array}{l}3^{r} d \text { Pillar savings } \\
(Y e s=1)\end{array}$ & & & $\begin{array}{c}0.018^{* * *} \\
(0.002)\end{array}$ \\
\hline Constant & & $\begin{array}{c}-0.007^{* * *} \\
(0.002)\end{array}$ & $\begin{array}{c}-0.029^{* * *} \\
(0.005)\end{array}$ \\
\hline Household Fixed Effects & Y & $\mathrm{Y}$ & $\mathrm{Y}$ \\
\hline MS Region Fixed Effects & $\mathrm{N}$ & $\mathrm{Y}$ & $\mathrm{Y}$ \\
\hline Observations & 34,478 & 38,776 & 36,012 \\
\hline $\mathrm{R}^{2}$ & 0.002 & 0.014 & 0.020 \\
\hline Adjusted $\mathrm{R}^{2}$ & -0.224 & 0.011 & 0.017 \\
\hline F Statistic & $\begin{array}{c}34.536^{* * *} \\
(\mathrm{df}=2 ; 28107)\end{array}$ & $\begin{array}{c}5.050^{* * *} \\
(\mathrm{df}=108 ; 38667)\end{array}$ & $\begin{array}{c}6.527^{* * *} \\
(\mathrm{df}=114 ; 35897)\end{array}$ \\
\hline
\end{tabular}

Note: ${ }^{*}<0.1 ;{ }^{* *} p<0.05 ;{ }^{* * *} p<0.01$, standard errors are clustered at the household level ( ${ }^{1}$ indicates an effect of an increase in gross income by 50,000 CHF/Month) 
Table 7: Heterogeneous Effect of Policy Shock on Homeownership

\begin{tabular}{|c|c|c|c|}
\hline & \multicolumn{3}{|c|}{ Transitioning to Homeownership (=1) } \\
\hline & $\begin{array}{l}\text { LPM } \\
(1)\end{array}$ & $\begin{array}{c}\text { LPM } \\
(2) \\
\end{array}$ & $\begin{array}{c}\text { LPM } \\
(3) \\
\end{array}$ \\
\hline $\begin{array}{l}{ }^{1} \text { Gross Income } \\
(\mathrm{CHF} / \text { Year })\end{array}$ & $\begin{array}{c}0.0041^{* *} \\
(0.00000)\end{array}$ & & \\
\hline Income $(25-50 q)$ & & $\begin{array}{c}0.007^{* * *} \\
(0.002)\end{array}$ & $\begin{array}{l}-0.001 \\
(0.002)\end{array}$ \\
\hline Income(50-75q) & & $\begin{array}{c}0.017^{* * *} \\
(0.002)\end{array}$ & $\begin{array}{l}0.004^{*} \\
(0.002)\end{array}$ \\
\hline Income $(75-100 q)$ & & $\begin{array}{c}0.030^{* * *} \\
(0.002)\end{array}$ & $\begin{array}{c}0.012^{* * *} \\
(0.003)\end{array}$ \\
\hline Policy Shock St-1 $_{t}$ & $\begin{array}{c}-0.023^{* * *} \\
(0.003)\end{array}$ & $\begin{array}{c}-0.011^{* * *} \\
(0.003)\end{array}$ & $\begin{array}{c}-0.009^{* * *} \\
(0.003)\end{array}$ \\
\hline Income $(25-50 q) *$ Policy Shock ${ }_{t-1}$ & & $\begin{array}{c}-0.013^{* *} \\
(0.005)\end{array}$ & $\begin{array}{c}-0.014^{* *} \\
(0.006)\end{array}$ \\
\hline Income $(50-75 q) *$ Policy Shock ${ }_{t-1}$ & & $\begin{array}{l}-0.011^{*} \\
(0.006)\end{array}$ & $\begin{array}{l}-0.013^{*} \\
(0.007)\end{array}$ \\
\hline Income $(75-100 q){ }^{*}$ Policy Shock Sh-1 $_{t}$ & & $\begin{array}{c}-0.039^{* * *} \\
(0.007)\end{array}$ & $\begin{array}{c}-0.039^{* * *} \\
(0.008)\end{array}$ \\
\hline $\begin{array}{l}\text { Nationality } \\
(\text { Swiss }=1)\end{array}$ & & & $\begin{array}{l}0.005^{* *} \\
(0.002)\end{array}$ \\
\hline $\begin{array}{l}\text { Civil Status } \\
(\text { Married = 1) }\end{array}$ & & & $\begin{array}{c}0.010^{* * *} \\
(0.002)\end{array}$ \\
\hline $\begin{array}{l}\text { Education } \\
\text { (in years) }\end{array}$ & & & $\begin{array}{c}0.001^{* *} \\
(0.0003)\end{array}$ \\
\hline Age & & & $\begin{array}{l}-0.0001^{*} \\
(0.00004)\end{array}$ \\
\hline $\begin{array}{l}\text { Family Type } \\
\text { (married with kids) }\end{array}$ & & & $\begin{array}{c}0.008^{* * *} \\
(0.003)\end{array}$ \\
\hline $\begin{array}{l}3^{r} d \text { Pillar savings } \\
(Y e s=1) \\
\text { Constant }\end{array}$ & & $\begin{array}{c}-0.012^{* * *} \\
(0.002)\end{array}$ & $\begin{array}{c}0.017^{* * *} \\
(0.002) \\
-0.025^{* * *} \\
(0.005)\end{array}$ \\
\hline $\begin{array}{l}\text { Household Fixed Effects } \\
\text { MS Region Fixed Effects } \\
\text { Observations } \\
\mathrm{R}^{2} \\
\text { Adjusted } \mathrm{R}^{2} \\
\text { F Statistic }\end{array}$ & $\begin{array}{c}\mathrm{Y} \\
\mathrm{N} \\
34,478 \\
0.002 \\
-0.224 \\
34.536^{* * *} \\
(\mathrm{df}=2 ; 28107)\end{array}$ & $\begin{array}{c}\mathrm{Y} \\
\mathrm{Y} \\
38,776 \\
0.016 \\
0.013 \\
5.720^{* * *} \\
(\mathrm{df}=112 ; 38663)\end{array}$ & $\begin{array}{c}\mathrm{Y} \\
\mathrm{Y} \\
36,012 \\
0.021 \\
0.018 \\
6.643^{* * *} \\
(\mathrm{df}=118 ; 35893)\end{array}$ \\
\hline
\end{tabular}

Note: ${ }^{*} p<0.1 ;^{* *} p<0.05 ;{ }^{* * *} p<0.01$, standard errors are clustered at the household level ( ${ }^{1}$ indicates an effect of an increase in gross incomes by 50,000 CHF/Month) 
Figure 10 shows the time variation in the percentage share of households that transition to ownership. I distinguish between households with below median income (red line) and households with above median income (green line). Median gross income in the sample is estimated to be CHF 90,000. As expected, high income households are ceteris paribus more likely to become homeowners. The blue dashed line indicates the real interest rate. The graph suggests a weak negative correlation between movements in the interest rate and the share of high income households that transition to ownership.

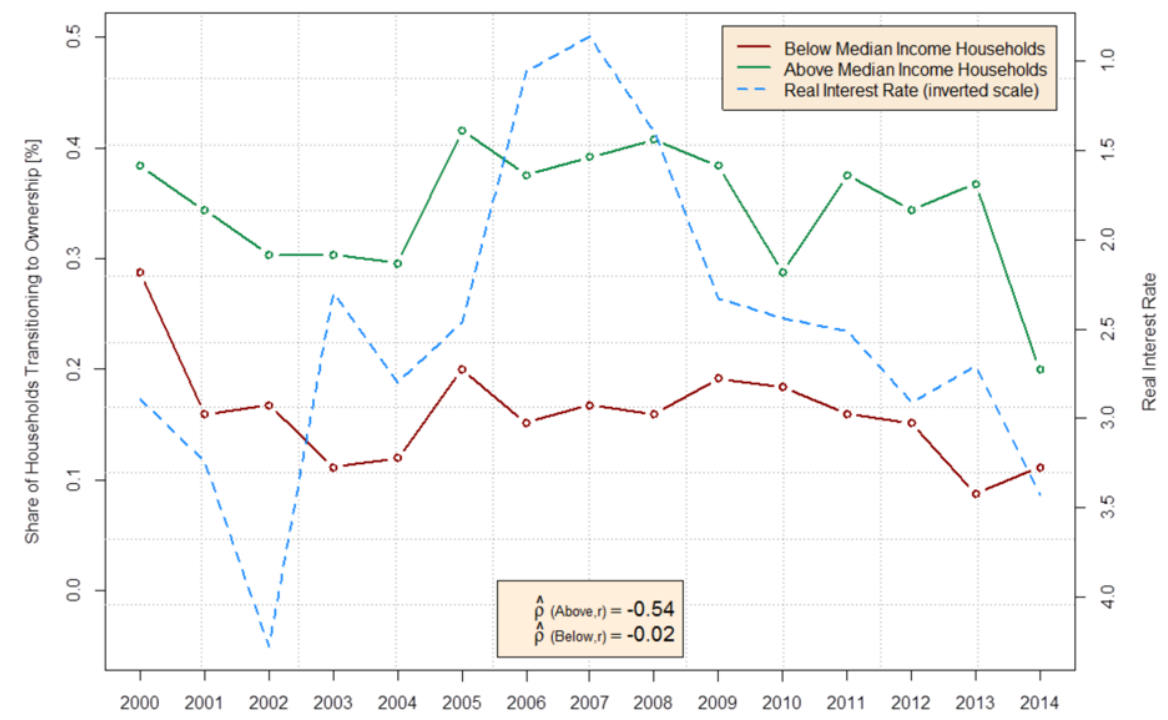

Figure 10: Tenure Choice

Source: Author's own calculation. The data is being retreived from SHP and SNB. The graph depicts the co-movement of interest rates with the tenure choice of the households. 
Table 8: Heterogeneous Effect of Policy Shock on Homeownership

\begin{tabular}{|c|c|c|}
\hline & \multicolumn{2}{|c|}{ Transitioning to Homeownership (=1) } \\
\hline & $\begin{array}{l}\text { LPM } \\
(1) \\
\end{array}$ & $\begin{array}{c}\text { LPM } \\
(2) \\
\end{array}$ \\
\hline $3^{r} d$ Pillar savings & $\begin{array}{c}0.009^{* * *} \\
(0.002)\end{array}$ & $\begin{array}{l}0.006^{* *} \\
(0.003)\end{array}$ \\
\hline Policy Shock $_{t-1}$ & $\begin{array}{c}-0.013^{* * *} \\
(0.003)\end{array}$ & $\begin{array}{c}-0.013^{* * *} \\
(0.003)\end{array}$ \\
\hline Policy Shock ${ }_{t-1} * 3^{r} d$ Pillar savings & $\begin{array}{c}-0.023^{* * *} \\
(0.005)\end{array}$ & $\begin{array}{c}-0.023^{* * *} \\
(0.005)\end{array}$ \\
\hline $\operatorname{Income}(>50 q)$ & $\begin{array}{c}0.009^{* * *} \\
(0.002)\end{array}$ & \\
\hline Income $(>50 \mathrm{q}) * 3^{r} d$ Pillar savings & $\begin{array}{c}0.014^{* * *} \\
(0.003)\end{array}$ & \\
\hline Income $(25-50 q)$ & & $\begin{array}{c}0.007^{* * *} \\
(0.002)\end{array}$ \\
\hline Income $(50-75 q)$ & & $\begin{array}{c}0.009^{* * *} \\
(0.002)\end{array}$ \\
\hline Income(75-100q) & & $\begin{array}{c}0.018^{* * *} \\
(0.004)\end{array}$ \\
\hline Income $(25-50 q) * 3^{r} d$ Pillar savings & & $\begin{array}{c}0.002 \\
(0.004)\end{array}$ \\
\hline Income $(50-75 q) * 3^{r} d$ Pillar savings & & $\begin{array}{c}0.012^{* * *} \\
(0.004)\end{array}$ \\
\hline Income $(75-100 \mathrm{q}) * 3^{r} d$ Pillar savings & & $\begin{array}{c}0.020^{* * *} \\
(0.005)\end{array}$ \\
\hline Constant & $\begin{array}{c}-0.012^{* * *} \\
(0.002)\end{array}$ & $\begin{array}{c}-0.016^{* * *} \\
(0.002)\end{array}$ \\
\hline Household Fixed Effects & $\mathrm{Y}$ & $\mathrm{Y}$ \\
\hline MS Region Fixed Effects & $\mathrm{N}$ & $\mathrm{Y}$ \\
\hline Observations & 36,054 & 36,054 \\
\hline $\mathrm{R}^{2}$ & 0.019 & 0.020 \\
\hline Adjusted $\mathrm{R}^{2}$ & 0.016 & 0.017 \\
\hline F Statistic & $\begin{array}{c}6.160^{* * *} \\
(\mathrm{df}=110 ; 35943)\end{array}$ & $\begin{array}{c}6.361^{* * *} \\
(\mathrm{df}=114 ; 35939)\end{array}$ \\
\hline
\end{tabular}

Note: $p<0.1 ;^{* *} p<0.05 ;{ }^{* * *} p<0.01$, standard errors are clustered at the household level 
In fact, the sample correlation between real interest rates and the transition share of high income households is -0.54 while the correlation for low income households in 0.02 and statistically insignificant. High income households are not only more likely to switch to home ownership, they also respond much stronger to lower interest rates, indicating that monetary policy can have some unintended consequences on wealth distribution and transfer, with high income households being the winners of an expansionary monetary policy at the cost of low income households.

\subsection{Alternative Policy Shocks: Further Robustness Checks}

Owing to results presented in this chapter, I further present a brief section on the robustness of the results. There can be enough good reasons for the reader to doubt whether a typical Swiss household may be in reality more concerned about the monetary policy.

Therefore, to mitigate these concerns I construct another similar shock to the one constructed in the identification section by using the long term variable mortgage rates rather than the 3 month CHF Libor. For a typical Swiss household, changes in the mortgage rate should be more relevant in general. Any changes in the monetary policy path are not only directly transmitted to the mortgage rates but also any unanticipated policy shocks are reflected in the mortgage rates. Moreover, the housing rents are also indexed to the mortgage rates since 2008 . 
I construct the policy shock for a typical household as follows:

$$
\operatorname{shock}_{t q}=i_{m_{t q d}}-i_{f_{t q d-15}}
$$

where, in equation $11, i_{l_{t q}}$ is the variable mortgage rate on the day of threemonth CHF LIBOR announcement $d$, of quarter $q$, in year $t . i_{f_{t q d-15}}$ is the implied interest from the Swiss futures contract on the three-month CHF LIBOR traded 15 days before the SNB monetary policy announcement ${ }^{8} d-$ 15 , of quarter $q$, in year $t$.

The shock $k_{t q}$ is the shock to the policy for a typical household at quarter $q$, in year $t$. The $s h o c k_{t q}$ is then annualized by taking the yearly average of the quarters.

The expected rate derived from the future's contract on the three-month CHF LIBOR, fifteen days before the announcement reflects the information set of the market expectation about the monetary policy rate and any deviation from the mortgage rate is the surprise component to a typical Swiss household. Thus, the difference can be interpreted as an unanticipated shock. This surprise component is exogenous.

The results presented in the following tables are robust to the results from the main specifications. This lends credibility to the main derived conclusions that in event of unanticipated monetary policy shocks wealthy households in the upper income quartile are more likely to switch to homeownership.

The results in Table 9 are estimated using equation 9 with a linear panel

\footnotetext{
${ }^{8}$ includes both scheduled and unscheduled announcements. Unscheduled announcements are those which are not held at the predefined regular quarterly decision events of the SNB.
} 
fixed effects model to identify the effect of a alternative policy shock to a typical Swiss household (constructed as above) on the user cost of homeownership and renting.

In light of hypothesis 1, the results in Table 9 column (1)-(3) suggests that the alternative policy shock to a typical Swiss household in the event of an unexpected expansionary monetary policy decreases the nominal user cost expenses for renters by 1.1 percent.

Whereas, a $1 \%$ (100 bps) shock to the monetary policy increases the cost for homeowners which is contrary to the hypothesis stated. These estimates provided validate the puzzling results in Table 5 concluding the mixed evidence for hypothesis 1 .

The results in Table 10 are estimated using equation 7 and equation 8 with a spatial lag panel fixed effects and random model to identify the effect of an alternative policy shock to a typical Swiss household (constructed as above) on the real house prices. The spatial lag parameter $\rho$ indicates a high degree of spatial dependence on the level of M.S. regions. The vacancy rate, $v$, has the expected negative sign and is highly statistically significant.

The alternative policy shock to a Swiss household similarly like an unanticipated policy shock that reduces the real mortgage rate by 1 percentage point has no effect on lower tier and medium real house prices, but increases upper tier real house prices by $0.5 \%$, as mentioned in column (3) of Table 10. The effect is highly significant and demonstrates the asymmetric nature of response of house prices to shocks in mortgage rates. The results also holds in the Panel (B) of Table 10 stating the spatial panel random effects specification (column (7)). The results are similar in direction to the results 
from the main specification.

The results in Table 11 are estimated using equation 10 with a linear probability model to identify the effect of a alternative policy shock to a typical Swiss household (constructed as above) on the probability of transitioning to homeownership. Following the same specification and method of grouping the households by gross income quartile, the results are robust in magnitude and direction to the results estimated in the main specification.

The coefficient for lagged mortgage rate shock has expected negative sign and is highly statistically significant. Holding everything else constant, a negative shock to the mortgage rate (expansionary monetary policy) of 1 percent (100 bps) is estimated to increase the probability of transitioning to home ownership by 0.5 percentage points for all households on average. However, this effect for richer households (column 2) is estimated to be much stronger at 0.9 percentage points $(0.4+0.5)$ and statistically significant. The effect becomes even stronger for households within the upper income quartile (Table 12, column (2)) with the increased probability of becoming a homeowner by 1.6 percentage points $(0.3+1.3)$.

The estimates are statistically significant. On an average, the richer households are 3.1 percentage points more probable to change their status as a homeowner relative to poor households (Table 11, column (2)). 


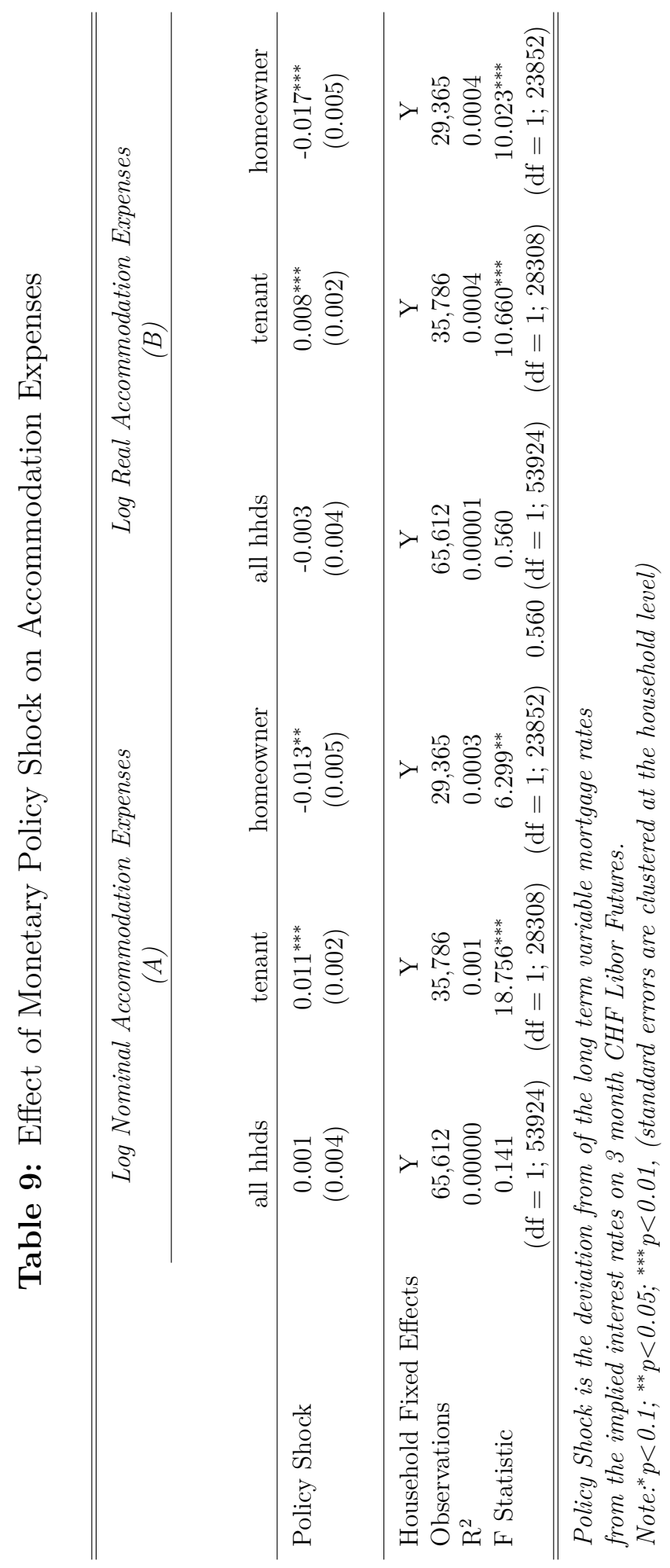




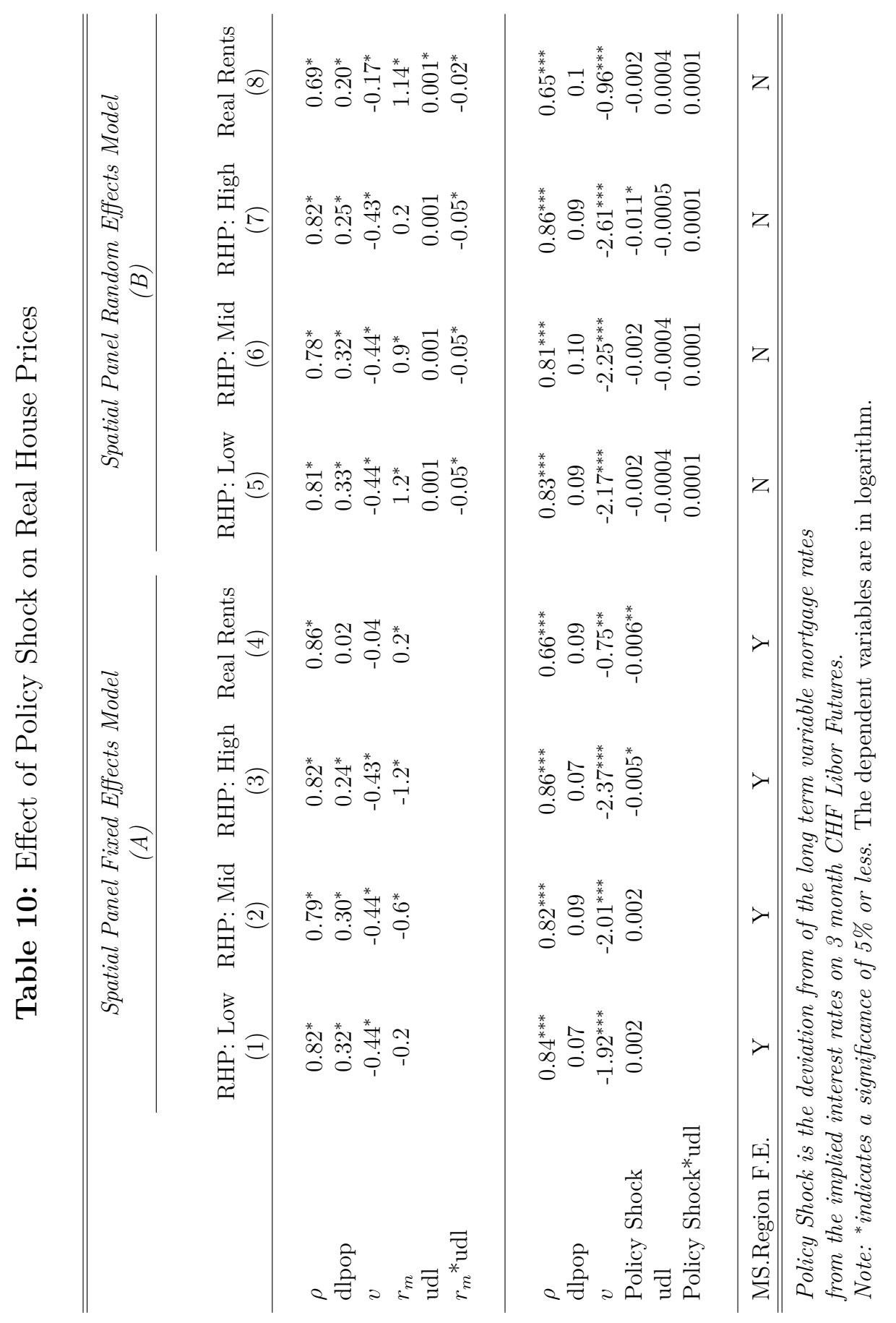


Table 11: Heterogeneous Effect of Policy Shock on Homeownership

\begin{tabular}{|c|c|c|c|}
\hline & \multicolumn{3}{|c|}{ Transitioning to Homeownership (=1) } \\
\hline & $\begin{array}{c}\text { LPM } \\
(1) \\
\end{array}$ & $\begin{array}{c}\text { LPM } \\
(2)\end{array}$ & $\begin{array}{c}\text { LPM } \\
(3) \\
\end{array}$ \\
\hline $\begin{array}{l}{ }^{1} \text { Gross Income } \\
(\mathrm{CHF} / \text { Year })\end{array}$ & $\begin{array}{c}0.0037^{* *} \\
(0.00000)\end{array}$ & & \\
\hline $\operatorname{Income}(>\mathrm{q} 50)$ & & $\begin{array}{c}0.031^{* * *} \\
(0.005)\end{array}$ & $\begin{array}{c}0.019^{* * *} \\
(0.006)\end{array}$ \\
\hline Policy Shock $_{t-1}$ & $\begin{array}{c}-0.005^{* * *} \\
(0.002)\end{array}$ & $\begin{array}{c}-0.004^{* * *} \\
(0.001)\end{array}$ & $\begin{array}{c}-0.004^{* * *} \\
(0.001)\end{array}$ \\
\hline Policy Shock ${ }_{t-1}{ }^{*}$ Income $(>\mathrm{q} 50)$ & & $\begin{array}{l}-0.005^{*} \\
(0.003)\end{array}$ & $\begin{array}{l}-0.005^{*} \\
(0.003)\end{array}$ \\
\hline $\begin{array}{l}\text { Nationality } \\
(\text { Swiss }=1)\end{array}$ & & & $\begin{array}{c}0.006^{* * *} \\
(0.002)\end{array}$ \\
\hline $\begin{array}{l}\text { Civil Status } \\
(\text { Married = 1) }\end{array}$ & & & $\begin{array}{l}0.011^{* * *} \\
(0.002)\end{array}$ \\
\hline $\begin{array}{l}\text { Education } \\
\text { (in years) }\end{array}$ & & & $\begin{array}{l}0.001^{* * *} \\
(0.0003)\end{array}$ \\
\hline Age & & & $\begin{array}{r}-0.0001^{* * *} \\
(0.00004)\end{array}$ \\
\hline $\begin{array}{l}\text { Family Type } \\
\text { (married with kids) }\end{array}$ & & & $\begin{array}{c}0.008^{* * *} \\
(0.003)\end{array}$ \\
\hline $3^{r} d$ Pillar savings & & & $\begin{array}{c}0.017^{* * *} \\
(0.002)\end{array}$ \\
\hline Constant & & $\begin{array}{c}0.005 \\
(0.003)\end{array}$ & $\begin{array}{c}-0.012^{* *} \\
(0.006)\end{array}$ \\
\hline Household Fixed Effects & $\mathrm{Y}$ & $\mathrm{Y}$ & $\mathrm{Y}$ \\
\hline MS Region Fixed Effects & $\mathrm{N}$ & $\mathrm{Y}$ & $\mathrm{Y}$ \\
\hline Observations & 34,478 & 38,776 & 36,012 \\
\hline $\mathrm{R}^{2}$ & 0.001 & 0.012 & 0.019 \\
\hline F Statistic & $15.097^{* * *}$ & $4.316^{* * *}$ & $5.983^{* * *}$ \\
\hline F Statistic & $(\mathrm{df}=2 ; 28107)$ & $(\mathrm{df}=108 ; 38667)$ & $(\mathrm{df}=114 ; 35897)$ \\
\hline
\end{tabular}

Note: $p<0.1 ;^{* *} p<0.05 ;^{* * *} p<0.01$, standard errors are clustered at the household level Policy Shock is the deviation from of the long term variable mortgage rates from the implied interest rates on 3 month CHF Libor Futures.

( ${ }^{1}$ indicates an effect of an increase in gross income by 50,000 CHF/Month) 
Table 12: Heterogeneous Effect of Policy Shock on Homeownership

\begin{tabular}{|c|c|c|c|}
\hline & \multicolumn{3}{|c|}{ Transitioning to Homeownership (=1) } \\
\hline & $\begin{array}{l}\text { LPM } \\
(1) \\
\end{array}$ & $\begin{array}{c}\text { LPM } \\
(2) \\
\end{array}$ & $\begin{array}{c}\text { LPM } \\
(3) \\
\end{array}$ \\
\hline $\begin{array}{l}{ }^{1} \text { Gross Income } \\
(\mathrm{CHF} / \text { Year })\end{array}$ & $\begin{array}{c}0.0037^{* *} \\
(0.00000)\end{array}$ & & \\
\hline Income(25-50q) & & $\begin{array}{c}0.016^{* * *} \\
(0.006)\end{array}$ & $\begin{array}{c}0.007 \\
(0.006)\end{array}$ \\
\hline Income $(50-75 q)$ & & $\begin{array}{c}0.022^{* * *} \\
(0.006)\end{array}$ & $\begin{array}{c}0.008 \\
(0.007)\end{array}$ \\
\hline Income(75-100q) & & $\begin{array}{c}0.061^{* * *} \\
(0.008)\end{array}$ & $\begin{array}{c}0.043^{* * *} \\
(0.009)\end{array}$ \\
\hline Policy Shock $t-1$ & $\begin{array}{c}-0.005^{* * *} \\
(0.002)\end{array}$ & $\begin{array}{l}-0.003^{*} \\
(0.001)\end{array}$ & $\begin{array}{l}-0.003^{*} \\
(0.002)\end{array}$ \\
\hline Income $(25-50 \mathrm{q}) *$ Policy Shock $_{t-1}$ & & $\begin{array}{l}-0.003 \\
(0.003)\end{array}$ & $\begin{array}{l}-0.003 \\
(0.003)\end{array}$ \\
\hline Income $(50-75 q){ }^{*}$ Policy Shock ${ }_{t-1}$ & & $\begin{array}{l}-0.002 \\
(0.003)\end{array}$ & $\begin{array}{l}-0.001 \\
(0.003)\end{array}$ \\
\hline Income $(75-100 q){ }^{*}$ Policy Shock ${ }_{t-1}$ & & $\begin{array}{c}-0.013^{* * *} \\
(0.004)\end{array}$ & $\begin{array}{c}-0.013^{* * *} \\
(0.004)\end{array}$ \\
\hline $\begin{array}{l}\text { Nationality } \\
(\text { Swiss }=1)\end{array}$ & & & $\begin{array}{c}0.005^{* * *} \\
(0.002)\end{array}$ \\
\hline $\begin{array}{l}\text { Civil Status } \\
(\text { Married = 1) }\end{array}$ & & & $\begin{array}{c}0.010^{* * *} \\
(0.002)\end{array}$ \\
\hline $\begin{array}{l}\text { Education } \\
\text { (in years) }\end{array}$ & & & $\begin{array}{c}0.0004 \\
(0.0003)\end{array}$ \\
\hline Age & & & $\begin{array}{c}-0.0001^{* * *} \\
(0.00004)\end{array}$ \\
\hline $\begin{array}{l}\text { Family Type } \\
\text { (married with kids) }\end{array}$ & & & $\begin{array}{c}0.007^{* * *} \\
(0.003)\end{array}$ \\
\hline $3^{r} d$ Pillar savings & & & $\begin{array}{c}0.016^{* * *} \\
(0.002)\end{array}$ \\
\hline Constant & & $\begin{array}{l}-0.005 \\
(0.004)\end{array}$ & $\begin{array}{c}-0.012^{*} \\
(0.006)\end{array}$ \\
\hline Household Fixed Effects & $\mathrm{Y}$ & $\mathrm{Y}$ & $\mathrm{Y}$ \\
\hline MS Region Fixed Effects & $\mathrm{N}$ & $\mathrm{Y}$ & $\mathrm{Y}$ \\
\hline Observations & 34,478 & 38,776 & 36,012 \\
\hline $\mathrm{R}^{2}$ & 0.001 & 0.014 & 0.020 \\
\hline F Statistic & $\begin{array}{c}15.097^{* * *} \\
(\mathrm{df}=2 ; 28107)\end{array}$ & $\begin{array}{c}4.913^{* * *} \\
(\mathrm{df}=112 ; 38663)\end{array}$ & $\begin{array}{c}6.070^{* * *} \\
(\mathrm{df}=118 ; 35893)\end{array}$ \\
\hline
\end{tabular}

Note:* $p<0.1 ;{ }^{* *} p<0.05 ;{ }^{* * *} p<0.01$, standard errors are clustered at the household level Policy Shock is the deviation from of the long term variable mortgage rates from the implied interest rates on 3 month CHF Libor Futures.

( ${ }^{1}$ indicates an effect of an increase in gross incomes by 50,000 CHF/Month) 


\section{Concluding Remarks}

The expansionary monetary policy affects the Swiss housing markets and households in a heterogeneous manner. The shock to the policy rate has a potential to increase homeownership for swiss households on average by 2.35 percentage points and for richer households with a probability of 3.45 percentage points. The expansionary monetary policy on homeownership rate cannot be attributed purely as causal relationship at this point but this finding is instructive. To understand the such an effect, I try to explore the potential user cost of housing channel by testing various hypothesis.

The results for the effect of monetary policy shock on the user cost of housing are mixed. While the tenants witness a decrease in their monthly user cost payments by $19 \%$, the effect is opposite for the homeowners thereby constraining the evidence. Moreover, an unanticipated negative monetary policy shock decreases rents in line with hypothesis. The effect on single family homes is however, contrary. This may indicate the importance of multi-family houses and / or apartment housing markets in the event of a monetary policy shock, the empirical analysis for which is out of the scope of this study. On the whole, the study finds that an expansionary monetary policy strongly affects the homeownership decisions. However, the results provides mixed support to the hypothesized user cost as a potential transmission channel which is subject to further empirical investigation. 


\section{References}

[1] Aladangady, Aditya. "Housing wealth and consumption: Evidence from geographically-linked microdata”. In: American Economic Review 107.11 (2017), pp. 3415-46.

[2] Albanesi, Stefania. "Inflation and inequality". In: Journal of Monetary Economics 54.4 (2007), pp. 1088-1114.

[3] Allen, Jason, Greenwald, Daniel, et al. "Managing a Housing Boom". In: 2018 Meeting Papers. 1310. Society for Economic Dynamics. 2018.

[4] Andrei, Daniel, Herskovic, Bernard, and Ledoit, Olivier. "The redistributive effects of monetary policy". In: Available at SSRN 2938163 (2017).

[5] Andrews, Dan, Sánchez, Aida Caldera, and Johansson, Åsa. "Housing markets and structural policies in OECD countries". In: (2011).

[6] Areosa, Waldyr and Areosa, Marta. "The inequality channel of monetary transmission". In: Banco Central do Brasil Working Paper 114 (2006).

[7] Bhattacharya, Joydeep, Haslag, Joseph, and Russell, Steven. "The role of money in two alternative models: When is the Friedman rule optimal, and why?" In: Journal of Monetary Economics 52.8 (2005), pp. 14011433. 
[8] Bourassa, Steven C and Hoesli, Martin. "Why do the Swiss rent?" In: The Journal of Real Estate Finance and Economics 40.3 (2010), pp. 286-309.

[9] Bourguignon, Francois and Morrisson, Christian. "Inequality and development: the role of dualism". In: Journal of development economics 57.2 (1998), pp. 233-257.

[10] Brueckner, Jan K. Lectures on urban economics. MIT Press, 2011.

[11] Bulir, Mr Ales and Gulde, Ms Anne Marie. Inflation and Income Distribution: Further Evidenceon Empirical Links. International Monetary Fund, 1995.

[12] Cloyne, James and Hürtgen, Patrick. "The macroeconomic effects of monetary policy: a new measure for the United Kingdom". In: American Economic Journal: Macroeconomics 8.4 (2016), pp. 75-102.

[13] Cysne, Rubens P, Maldonado, Wilfredo L, and Monteiro, Paulo Klinger. "Inflation and income inequality: A shopping-time approach". In: Journal of Development Economics 78.2 (2005), pp. 516-528.

[14] Di Maggio, Marco et al. "Interest rate pass-through: Mortgage rates, household consumption, and voluntary deleveraging". In: American Economic Review 107.11 (2017), pp. 3550-88.

[15] Doepke, Matthias and Schneider, Martin. "Inflation and the redistribution of nominal wealth". In: Journal of Political Economy 114.6 (2006), pp. 1069-1097. 
[16] Easterly, William. "The lost decades: developing countries' stagnation in spite of policy reform 1980-1998". In: Journal of Economic growth 6.2 (2001), pp. 135-157.

[17] Ehrlich, Maximilian von, Basten, Christoph, and Lassmann, Andrea. "Income Taxes, Sorting, and the Costs of Housing: Evidence from Municipal Boundaries in Switzerland". In: KOF Working Papers 362 (2014).

[18] Elhorst, J Paul. Spatial econometrics: from cross-sectional data to spatial panels. Vol. 479. Springer, 2014.

[19] Erosa, Andrés and Ventura, Gustavo. "On inflation as a regressive consumption tax". In: Journal of Monetary Economics 49.4 (2002), pp. $761-795$.

[20] Favara, Giovanni and Imbs, Jean. "Credit supply and the price of housing". In: American Economic Review 105.3 (2015), pp. 958-92.

[21] Füss, Roland and Zietz, Joachim. "The economic drivers of differences in house price inflation rates across MSAs". In: Journal of Housing Economics 31 (2016), pp. 35-53.

[22] Gertler, Mark and Karadi, Peter. "Monetary policy surprises, credit costs, and economic activity". In: American Economic Journal: Macroeconomics 7.1 (2015), pp. 44-76.

[23] Glaeser, Edward L, Gyourko, Joseph, and Saiz, Albert. "Housing supply and housing bubbles". In: Journal of urban Economics 64.2 (2008), pp. 198-217. 
[24] Gürkaynak, Refet S, Sack, Brian P, and Swanson, Eric T. "Marketbased measures of monetary policy expectations". In: Journal of Business EJ Economic Statistics 25.2 (2007), pp. 201-212.

[25] Heathcote, Jonathan, Perri, Fabrizio, and Violante, Giovanni L. "Unequal we stand: An empirical analysis of economic inequality in the United States, 1967-2006". In: Review of Economic dynamics 13.1 (2010), pp. 15-51.

[26] Hilber, Christian AL, Mayer, Christopher J, et al. "Land supply, house price capitalization, and local spending on schools". In: The Wharton School, University of Pennsylvania http://realestate. wharton. upenn. edu/newsletter/392. pdf (downloaded 17/12/2010) (2001).

[27] Iacoviello, Matteo and Neri, Stefano. "Housing market spillovers: evidence from an estimated DSGE model". In: American Economic Journal: Macroeconomics 2.2 (2010), pp. 125-64.

[28] Kumhof, Michael, Rancière, Romain, and Winant, Pablo. "Inequality, leverage, and crises". In: American Economic Review 105.3 (2015), pp. $1217-45$.

[29] Kuttner, Kenneth N. "Monetary policy surprises and interest rates: Evidence from the Fed funds futures market". In: Journal of monetary economics 47.3 (2001), pp. 523-544.

[30] Kuznets, Simon. "Economic growth and income inequality". In: The American economic review 45.1 (1955), pp. 1-28.

[31] Al-Marhubi, Fahim. "A note on the link between income inequality and inflation". In: Economics Letters 55.3 (1997), pp. 317-319. 
[32] Mian, Atif, Rao, Kamalesh, and Sufi, Amir. "Household balance sheets, consumption, and the economic slump". In: The Quarterly Journal of Economics 128.4 (2013), pp. 1687-1726.

[33] Palivos, Theodore. "Optimal monetary policy with heterogeneous agents: a case for inflation". In: Oxford Economic Papers 57.1 (2005), pp. 3450.

[34] Rajan, Raghuram G. Fault Lines-Verwerfungen: Warum sie noch immer die Weltwirtschaft bedrohen und was jetzt zu tun ist. FinanzBuch Verlag, 2012 .

[35] Romer, Christina D and Romer, David H. Monetary policy and the well-being of the poor. Tech. rep. National bureau of economic research, 1998.

[36] Saiki, Ayako and Frost, Jon. "Does unconventional monetary policy affect inequality? Evidence from Japan". In: Applied Economics 46.36 (2014), pp. 4445-4454.

[37] Saiz, Albert. "The geographic determinants of housing supply". In: The Quarterly Journal of Economics 125.3 (2010), pp. 1253-1296.

[38] Schularick, Moritz and Taylor, Alan M. "Credit booms gone bust: Monetary policy, leverage cycles, and financial crises, 1870-2008". In: American Economic Review 102.2 (2012), pp. 1029-61.

[39] Shi, Shouyong. "Money, capital, and redistributive effects of monetary policies". In: Journal of Economic Dynamics and Control 23.4 (1999), pp. $565-590$. 
[40] Steiner, Elizabeth. "Estimating a stock-flow model for the Swiss housing market". In: Swiss Journal of Economics and Statistics 146.3 (2010), pp. 601-627.

[41] Werczberger, Elia. "Home ownership and rent control in Switzerland". In: Housing Studies 12.3 (1997), pp. 337-353. 
10 Appendix 


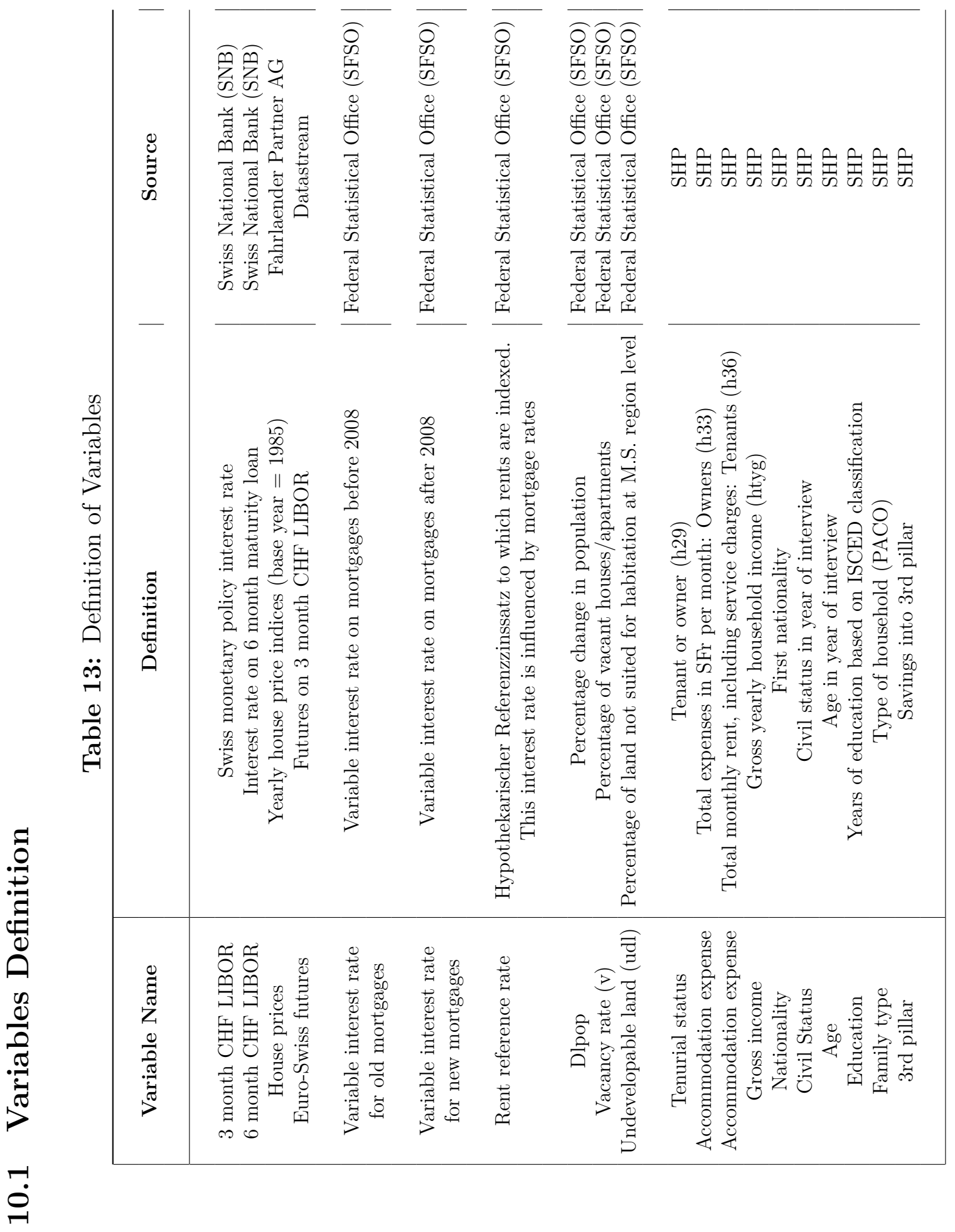




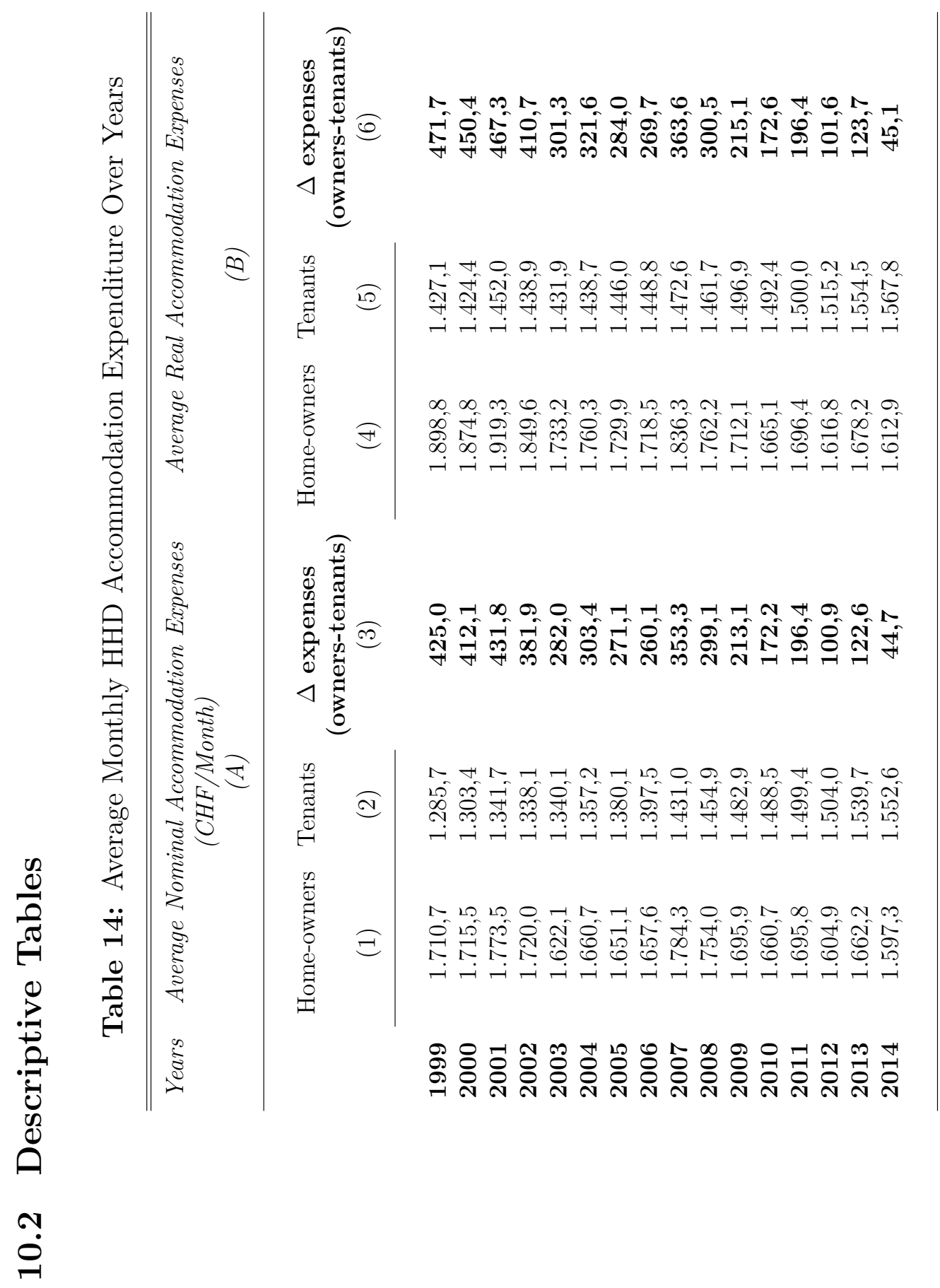




\subsection{Descriptive Graphs}

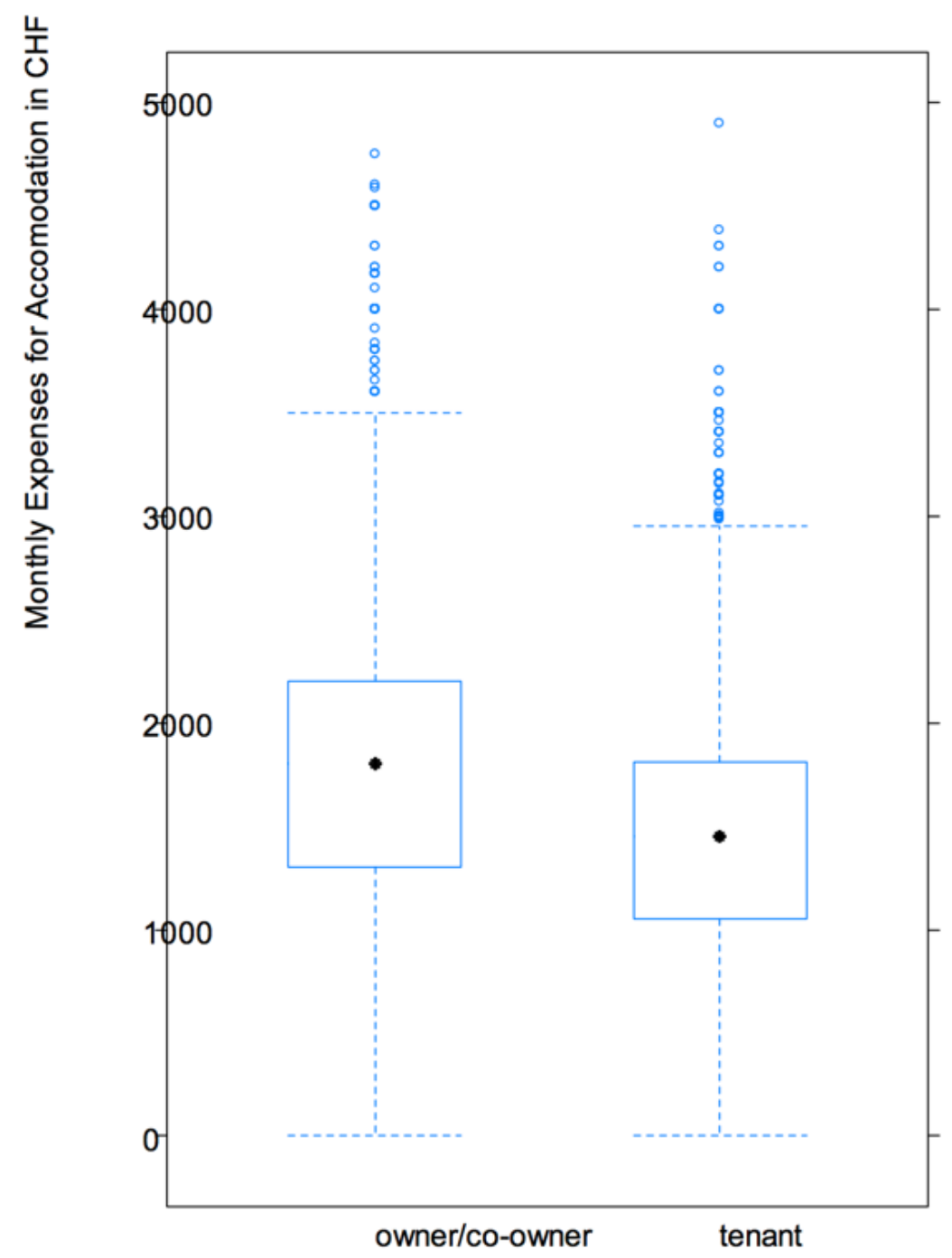

Figure 11: Distribution Monthly Expenditures:

By Housing Tenure

Figure 11 shows the distribution of monthly user cost expenses for accommodation for households that started as tenants and then became home owners. While tenants, households paid on average $\mathrm{CHF}$ 1,496 per month while as owners their monthly expenses increased only slightly to CHF 1,799. This shows that the financial burden from owning a house is comparable to renting. 


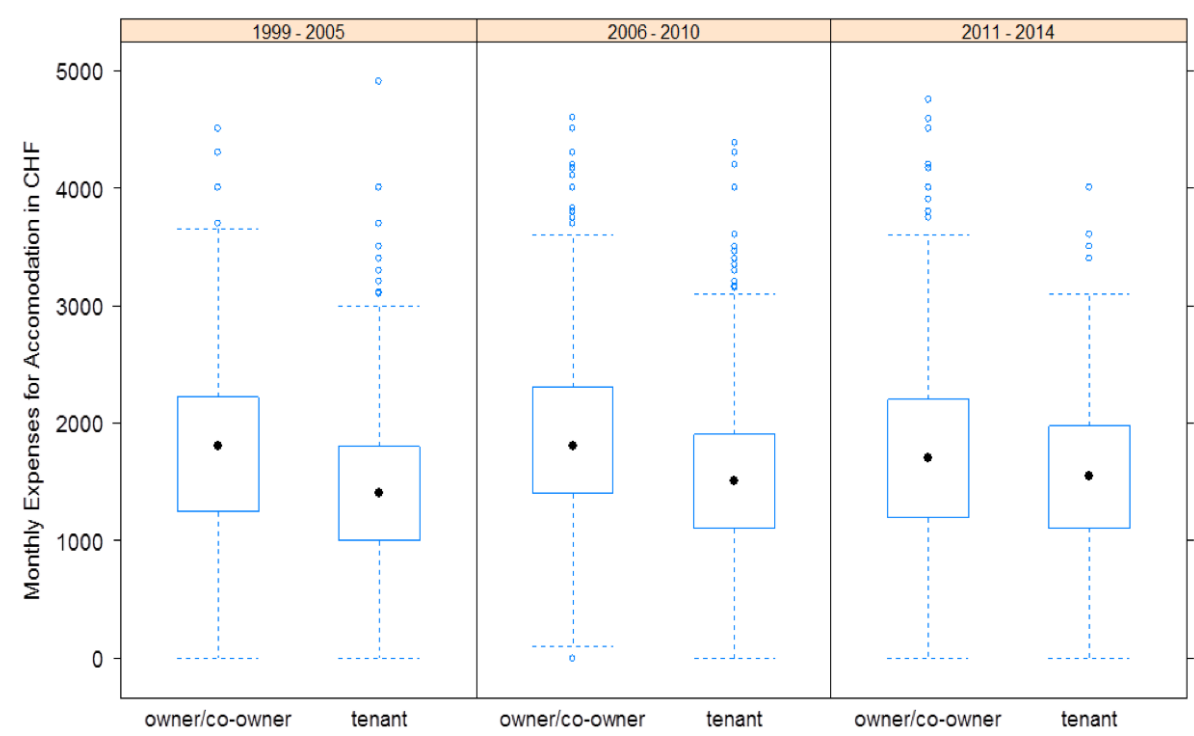

Figure 12: Distribution of Monthly Housing Expenditures: By Year

Figure 12 shows the same distribution of monthly expenses across time. Even though in absolute prices homeowners pay more CHF per month on average compared to the renters but this difference in average monthly accommodation expenses has gradually declined over the years making homeownership more attractive. 


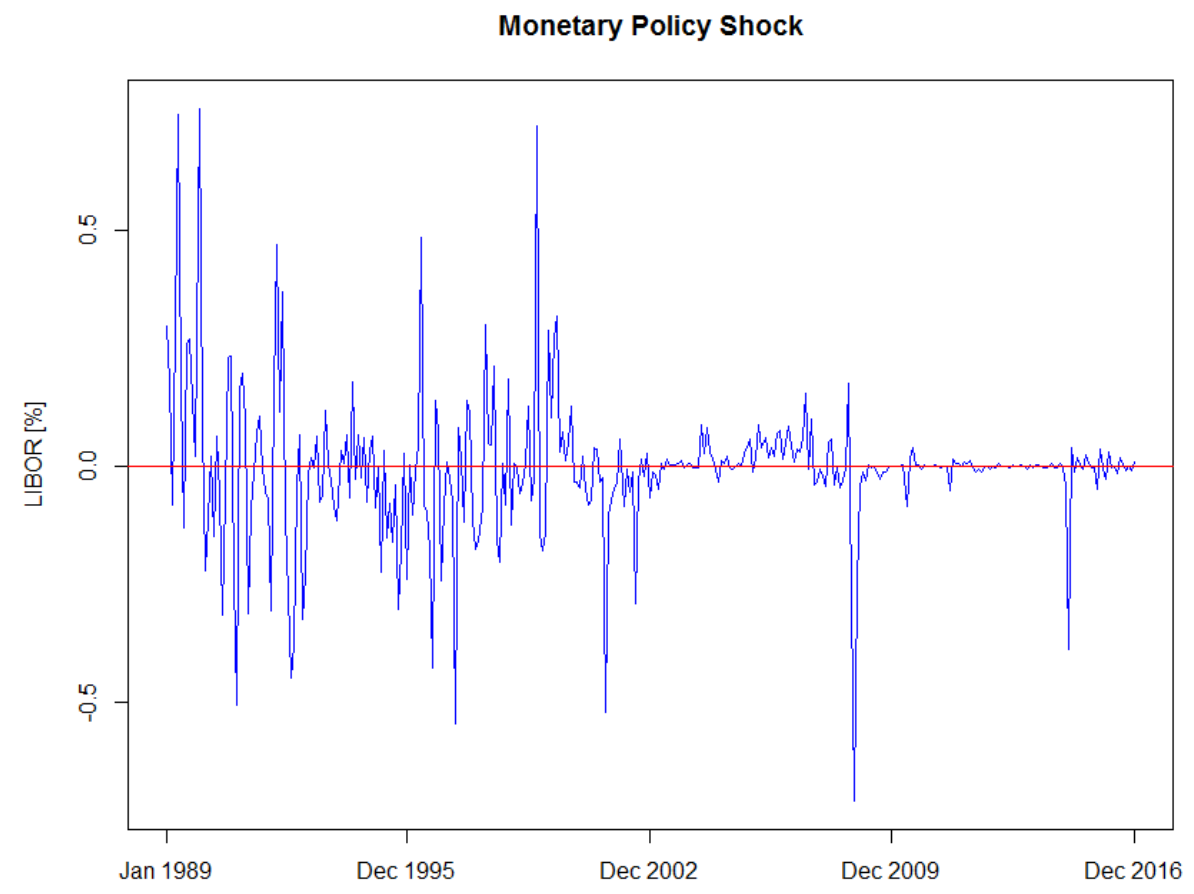

Figure 13: Monthly Monetary Policy Shock

Source: Author's own calculation. The figure depicts the monthly shock to the Swiss monetary policy i.e., 3- month CHF LIBOR from 1999-2016. 


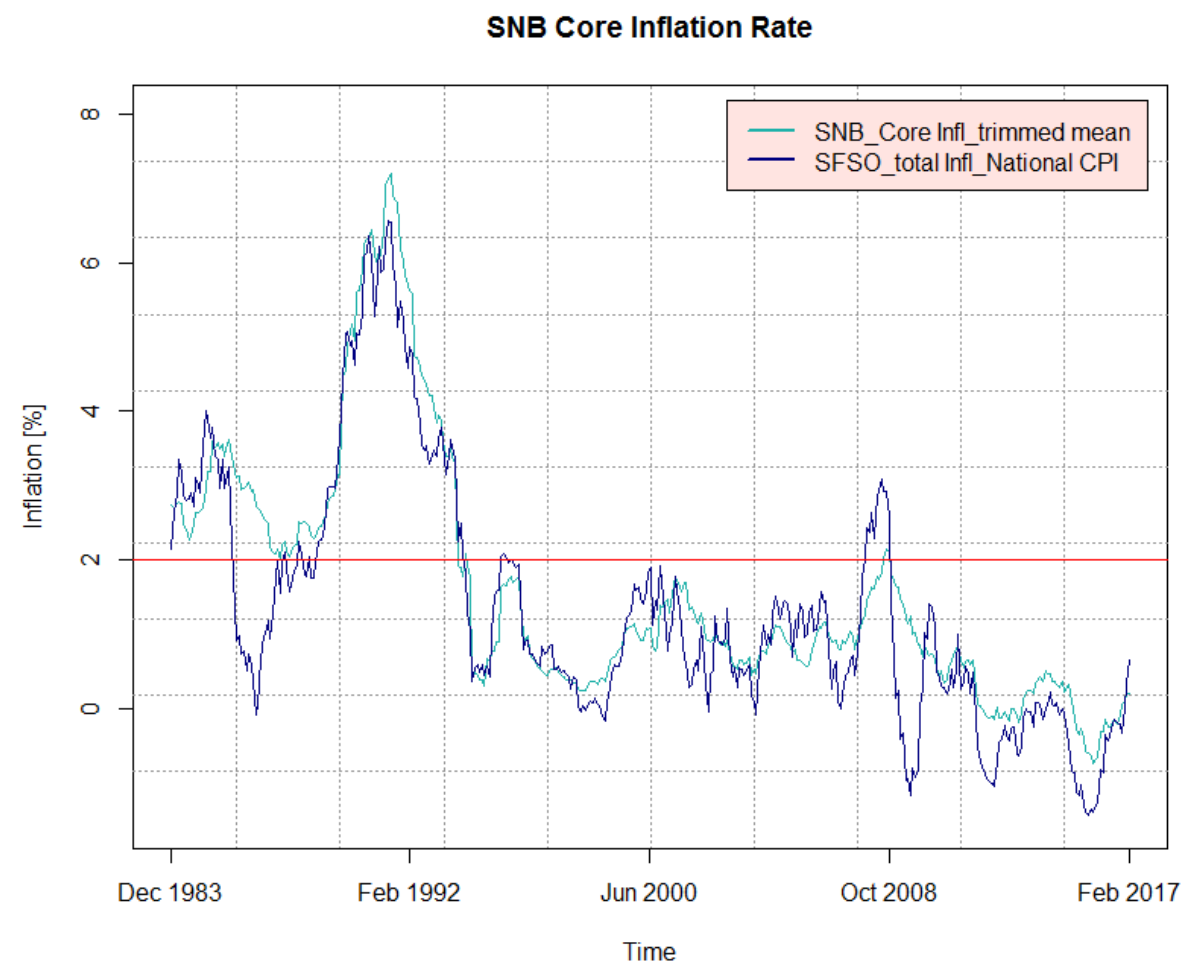

Figure 14: SNB Inflation Rate

Source: Author's own calculation. The figure depicts the core monthly inflation rate in Switzerland from December 1983 to March 2017. The data was retrieved from SNB. 
10.4 Robustness 
10 Appendix

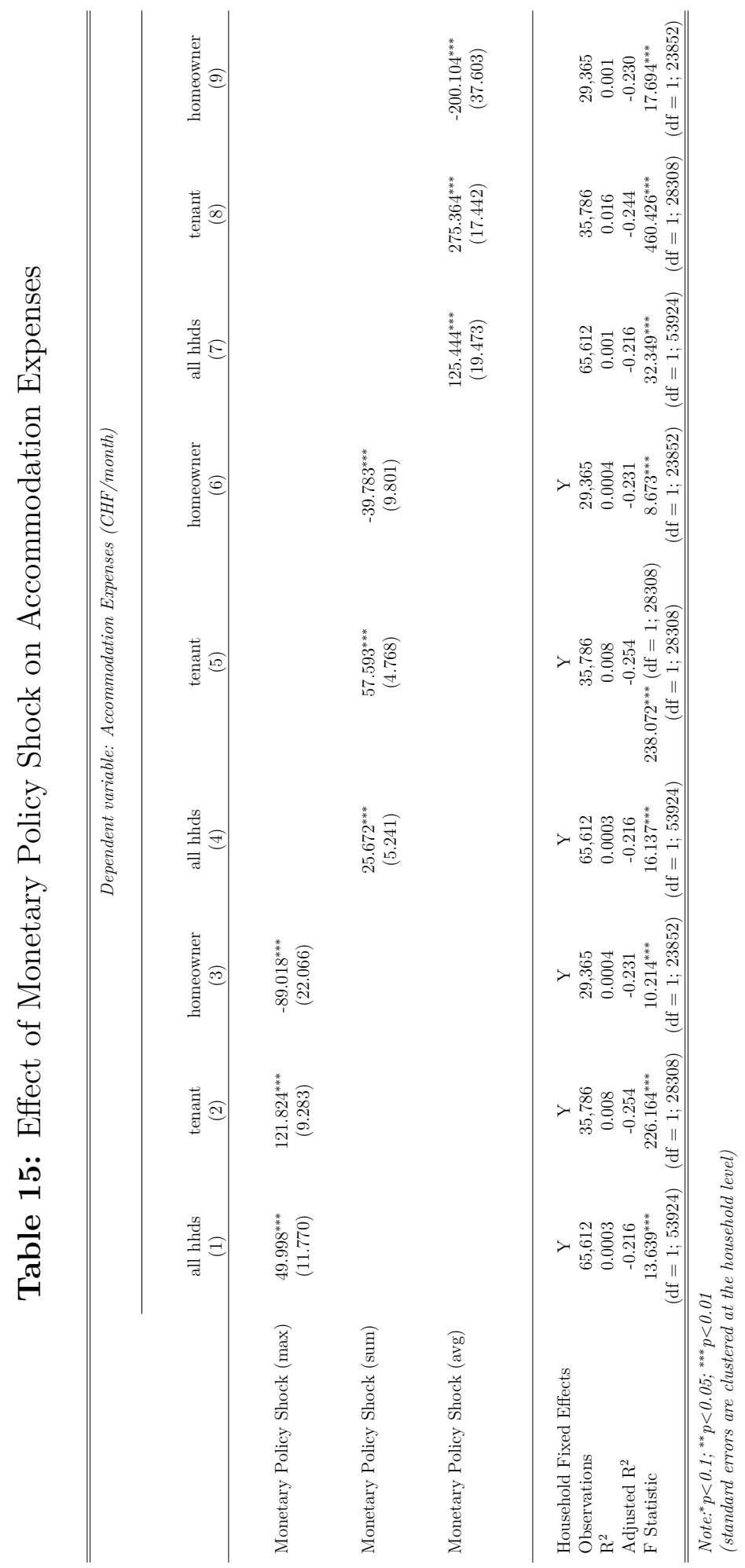


10 Appendix

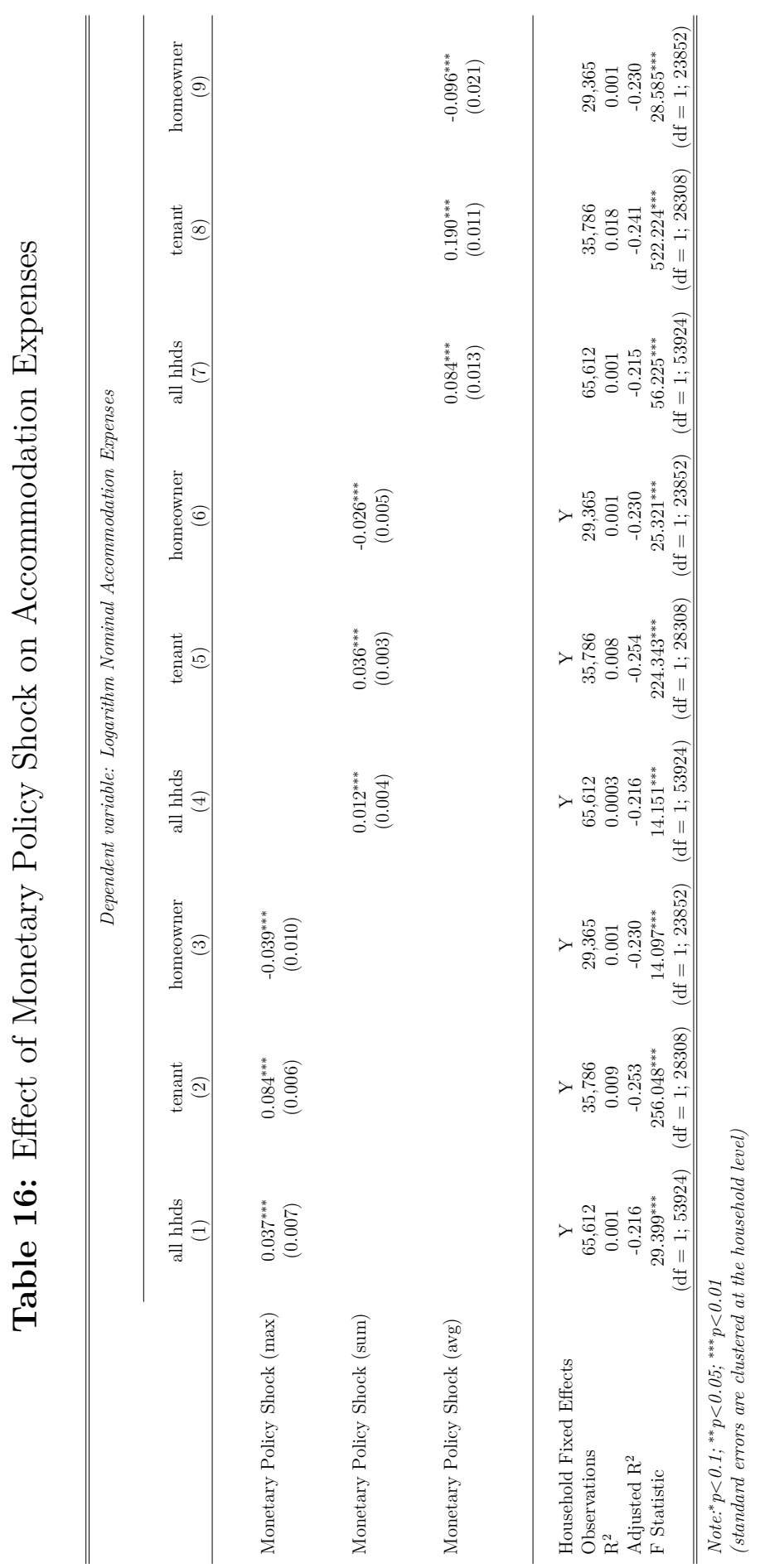




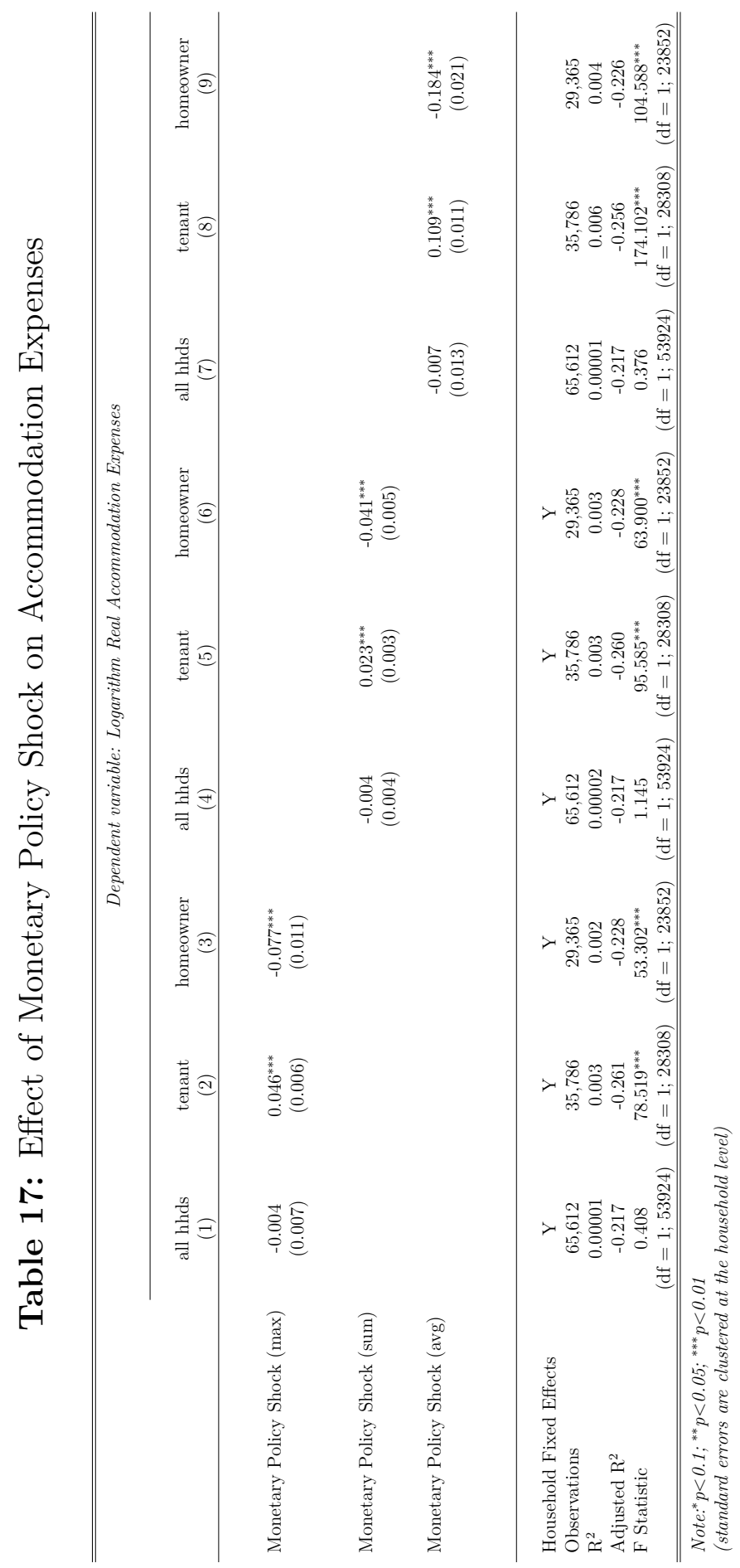




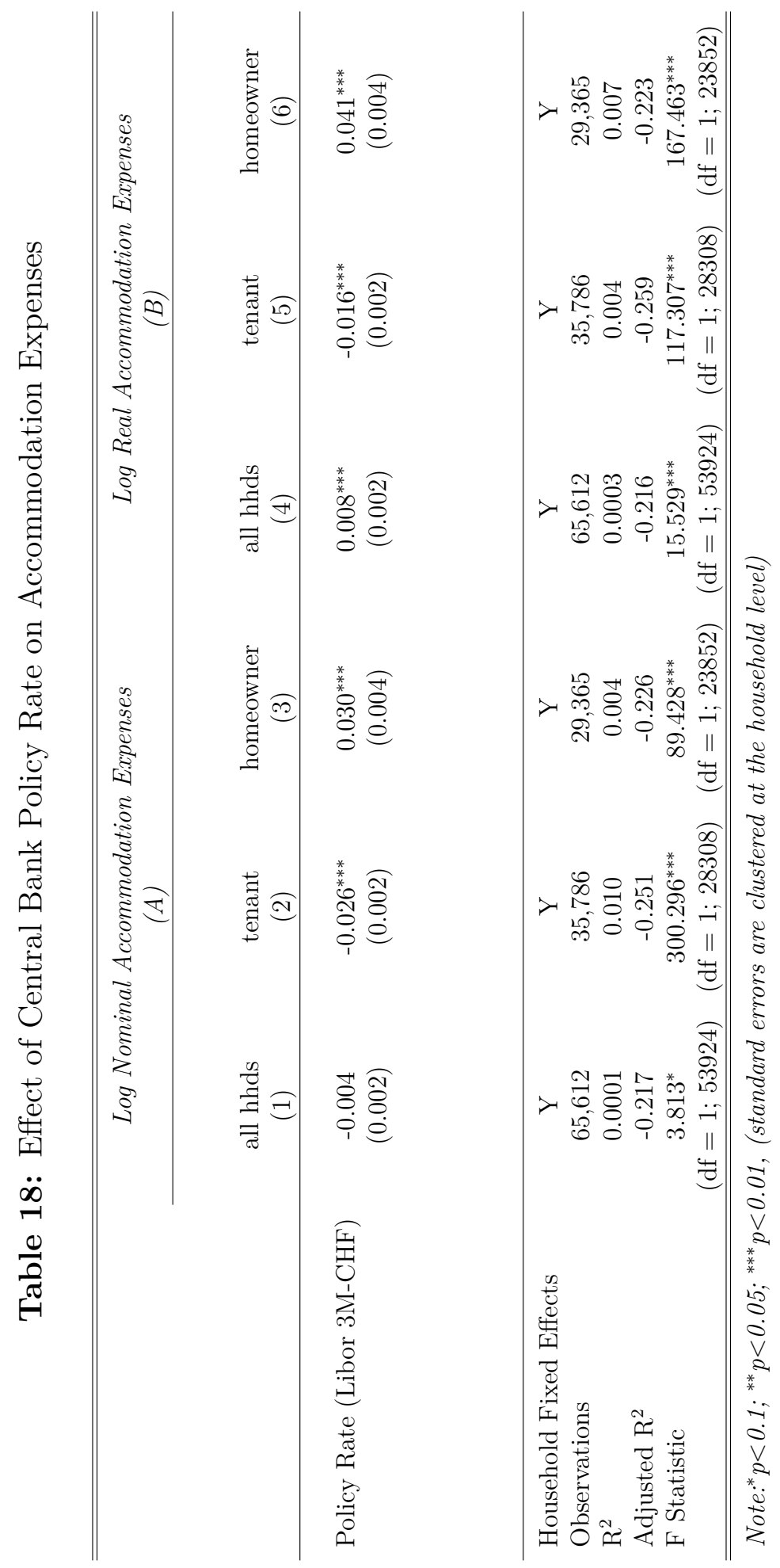




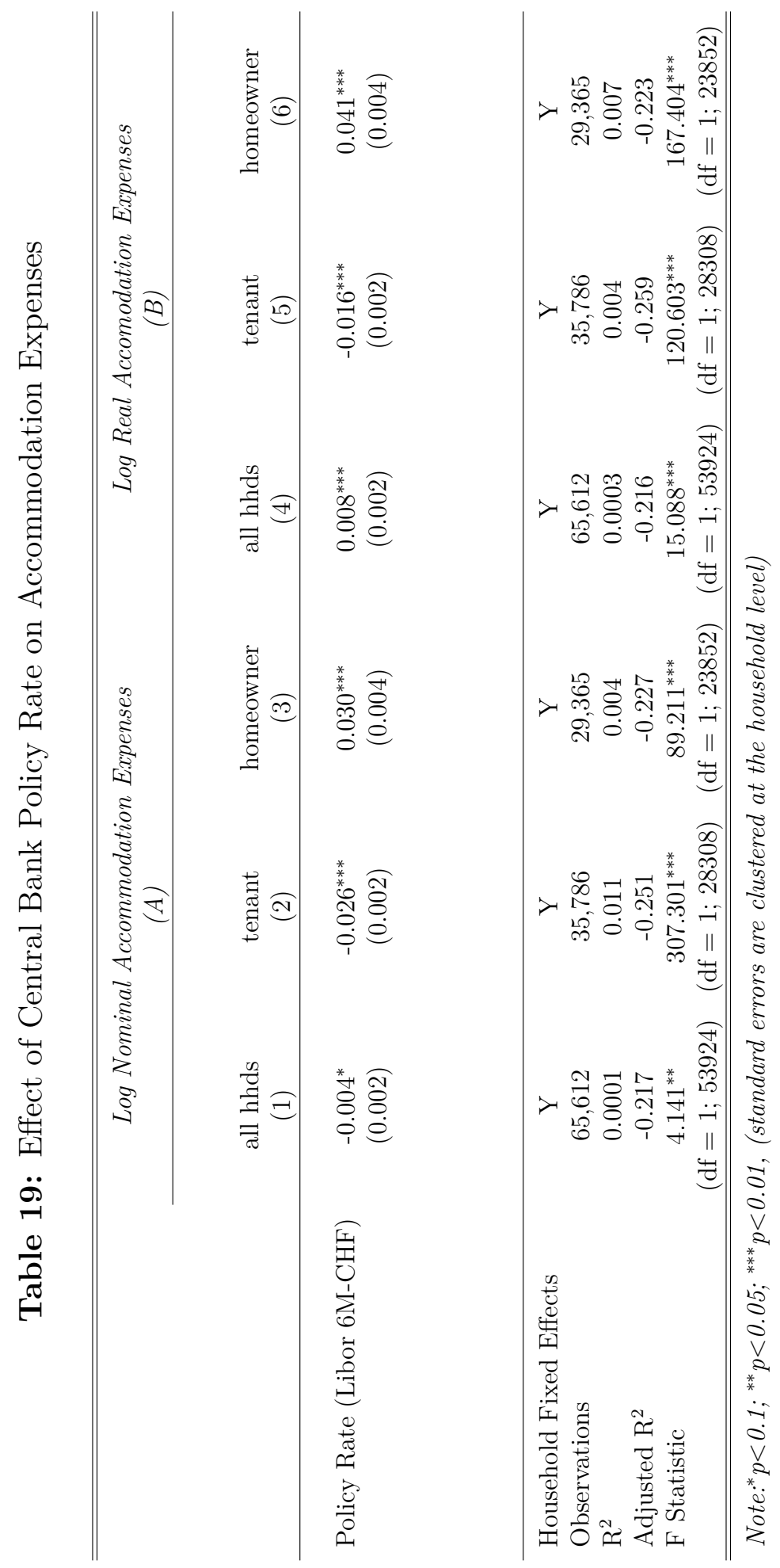




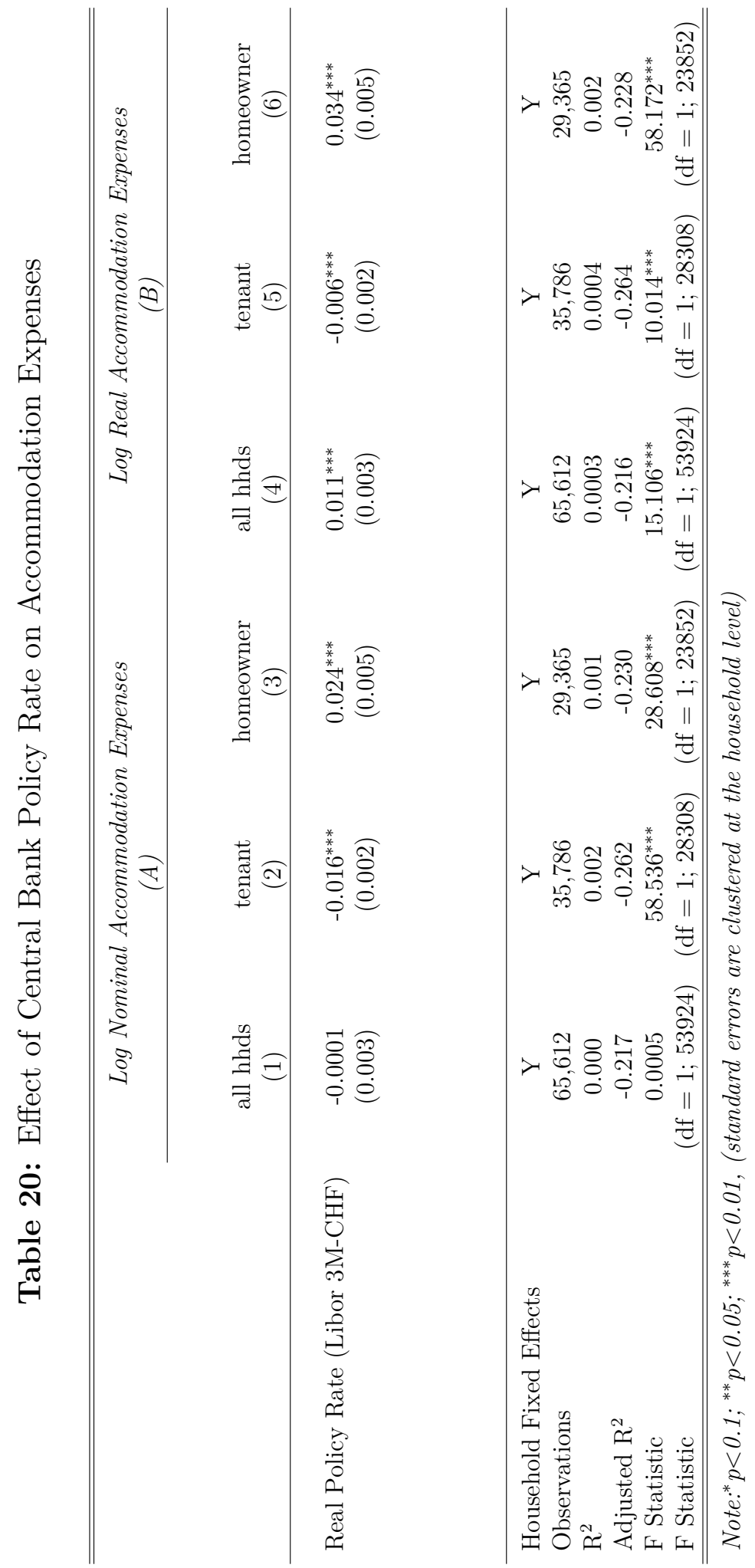




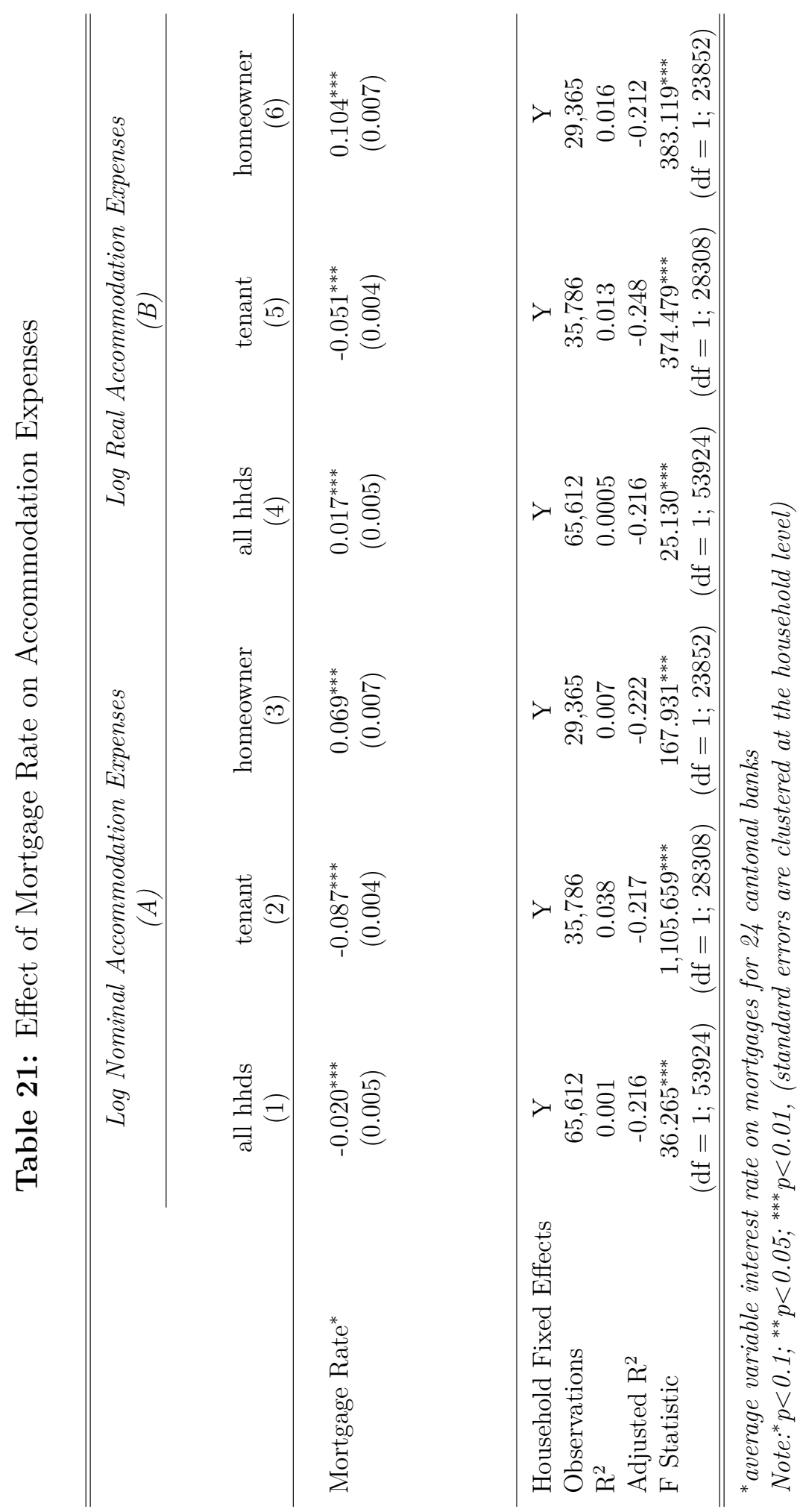




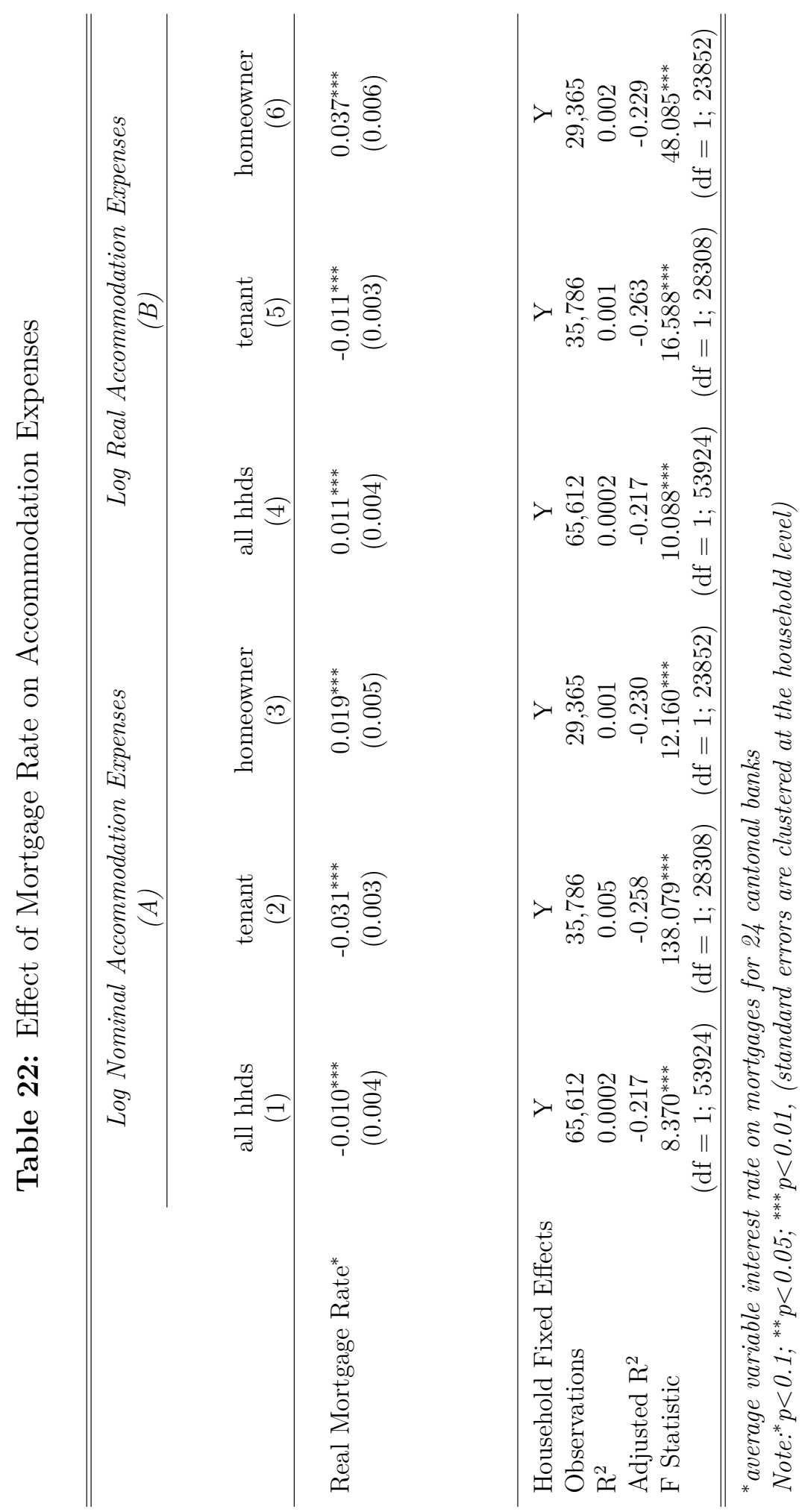


Table 23: Heterogeneous Effect of Policy Shock on Homeownership (Full Sample)

\begin{tabular}{|c|c|c|c|}
\hline & \multicolumn{3}{|c|}{ Transitioning to Homeownership (=1) } \\
\hline & $\begin{array}{l}\text { LPM } \\
(1)\end{array}$ & $\begin{array}{l}\text { LPM } \\
(2)\end{array}$ & $\begin{array}{c}\mathrm{LPM} \\
(3)\end{array}$ \\
\hline $\begin{array}{l}{ }^{1} \text { Gross Income } \\
(\mathrm{CHF} / \text { Year })\end{array}$ & $\begin{array}{l}0.0003 \\
(0.000)\end{array}$ & & \\
\hline Policy Shock Sh-1 $_{t}$ & $\begin{array}{c}-0.012^{* * *} \\
(0.002)\end{array}$ & $\begin{array}{c}-0.011^{* * *} \\
(0.001)\end{array}$ & $\begin{array}{c}-0.005^{* * *} \\
(0.001)\end{array}$ \\
\hline $\operatorname{Income}(>50 q)$ & & $\begin{array}{c}0.004^{* * *} \\
(0.001)\end{array}$ & \\
\hline Income $(>50 q){ }^{*}$ Policy Shock Sh-1 $_{t}$ & & $\begin{array}{c}-0.011^{* * *} \\
(0.002)\end{array}$ & \\
\hline Income $(25-50 q)$ & & & $\begin{array}{c}0.004^{* * *} \\
(0.001)\end{array}$ \\
\hline Income $(50-75 q)$ & & & $\begin{array}{c}0.006^{* * *} \\
(0.001)\end{array}$ \\
\hline Income(75-100q) & & & $\begin{array}{c}0.005^{* * *} \\
(0.001)\end{array}$ \\
\hline Income (25-50q)*Policy Shock $_{t-1}$ & & & $\begin{array}{c}-0.010^{* * *} \\
(0.003)\end{array}$ \\
\hline Income $(50-75 q) *$ Policy Shock $_{t-1}$ & & & $\begin{array}{c}-0.014^{* * *} \\
(0.003)\end{array}$ \\
\hline Income $(75-100 q) *$ Policy Shock $_{t-1}$ & & & $\begin{array}{c}-0.019^{* * *} \\
(0.003)\end{array}$ \\
\hline Constant & & $\begin{array}{l}0.0004 \\
(0.001)\end{array}$ & $\begin{array}{l}-0.001 \\
(0.001)\end{array}$ \\
\hline Household Fixed Effects & $\mathrm{Y}$ & $\mathrm{Y}$ & $\mathrm{Y}$ \\
\hline MS Region Fixed Effects & $\mathrm{N}$ & $\mathrm{Y}$ & $\mathrm{Y}$ \\
\hline Observations & 59,945 & 67,859 & 67,859 \\
\hline $\mathrm{R}^{2}$ & 0.001 & 0.005 & 0.006 \\
\hline Adjusted $\mathrm{R}^{2}$ & -0.222 & 0.004 & 0.004 \\
\hline F Statistic & $\begin{array}{c}31.561^{* * *} \\
(\mathrm{df}=2 ; 48994)\end{array}$ & $\begin{array}{c}3.307^{* * *} \\
(\mathrm{df}=108 ; 67750)\end{array}$ & $\begin{array}{c}3.520^{* * *} \\
(\mathrm{df}=112 ; 67746)\end{array}$ \\
\hline
\end{tabular}

Note: ${ }^{*}<<0.1 ;^{* *} p<0.05 ;{ }^{* * *} p<0.01$, standard errors are clustered at the household level ( ${ }^{1}$ indicates an effect of an increase in gross incomes by 50,000 CHF/Month) 
Table 24: Heterogeneous Effect of Policy Shock on Renting (Initial Homeowners)

\begin{tabular}{|c|c|c|c|}
\hline & \multicolumn{3}{|c|}{ Transitioning to Renting (=1) } \\
\hline & $\begin{array}{l}\mathrm{LPM} \\
(1)\end{array}$ & $\begin{array}{l}\text { LPM } \\
(2)\end{array}$ & $\begin{array}{c}\text { LPM } \\
(3)\end{array}$ \\
\hline $\begin{array}{c}{ }^{1} \text { Gross Income } \\
(\mathrm{CHF} / \text { Year })\end{array}$ & $\begin{array}{c}-0.0016^{* * *} \\
(0.000)\end{array}$ & & \\
\hline Policy Shock $_{t-1}$ & $\begin{array}{l}-0.001 \\
(0.003)\end{array}$ & $\begin{array}{c}-0.013^{* * *} \\
(0.003)\end{array}$ & $\begin{array}{c}-0.017^{* * *} \\
(0.005)\end{array}$ \\
\hline $\operatorname{Income}(>50 q)$ & & $\begin{array}{c}-0.003^{* *} \\
(0.001)\end{array}$ & \\
\hline Income $(>50 q) *$ Policy Shock $_{t-1}$ & & $\begin{array}{c}0.007^{*} \\
(0.004)\end{array}$ & \\
\hline Income $(25-50 q)$ & & & $\begin{array}{c}-0.007^{* * *} \\
(0.002)\end{array}$ \\
\hline Income $(50-75 q)$ & & & $\begin{array}{c}-0.005^{* *} \\
(0.002)\end{array}$ \\
\hline Income(75-100q) & & & $\begin{array}{c}-0.009^{* * *} \\
(0.002)\end{array}$ \\
\hline Income $(25-50 q) *$ Policy Shock S $_{t-1}$ & & & $\begin{array}{c}0.008 \\
(0.007)\end{array}$ \\
\hline Income $(50-75 q) *$ Policy Shock $_{t-1}$ & & & $\begin{array}{c}0.011 \\
(0.007)\end{array}$ \\
\hline Income(75-100q)*Policy Shock Sh-1 $_{t}$ & & & $\begin{array}{c}0.012^{*} \\
(0.007)\end{array}$ \\
\hline Constant & & $\begin{array}{c}0.033^{* * *} \\
(0.009)\end{array}$ & $\begin{array}{c}0.037^{* * *} \\
(0.009)\end{array}$ \\
\hline Household Fixed Effects & $\mathrm{Y}$ & $\mathrm{Y}$ & $\mathrm{Y}$ \\
\hline MS Region Fixed Effects & $\mathrm{N}$ & $\mathrm{Y}$ & $\mathrm{Y}$ \\
\hline Observations & 25,376 & 28,957 & 28,957 \\
\hline $\mathrm{R}^{2}$ & 0.001 & 0.007 & 0.007 \\
\hline Adjusted $\mathrm{R}^{2}$ & -0.217 & 0.003 & 0.003 \\
\hline F Statistic & $5.952^{* * *}$ & $1.758^{* * *}$ & $1.898^{* * *}$ \\
\hline F Statistic & $(\mathrm{df}=2 ; 20837)$ & $(\mathrm{df}=108 ; 28848)$ & $(\mathrm{df}=112 ; 28844)$ \\
\hline
\end{tabular}

Note: ${ }^{*}<<0.1 ;^{* *} p<0.05 ;{ }^{* * *} p<0.01$, standard errors are clustered at the household level ( ${ }^{1}$ indicates an effect of an increase in gross incomes by 50,000 CHF/Month) 
Table 25: Heterogeneous Effect of Policy Shock on Renting (Initial Homeowners)

\begin{tabular}{|c|c|c|}
\hline & \multicolumn{2}{|c|}{ Transitioning to Renting (=1) } \\
\hline & $\begin{array}{c}\text { LPM } \\
(1) \\
\end{array}$ & $\begin{array}{c}\text { LPM } \\
(2) \\
\end{array}$ \\
\hline $3^{r} d$ Pillar savings & $\begin{array}{c}-0.012^{* * *} \\
(0.002)\end{array}$ & $\begin{array}{c}-0.012^{* * *} \\
(0.003)\end{array}$ \\
\hline Policy Shock $_{t-1}$ & $\begin{array}{l}-0.007 \\
(0.005)\end{array}$ & $\begin{array}{l}-0.007 \\
(0.005)\end{array}$ \\
\hline Policy Shock ${ }_{t-1} * 3^{r} d$ Pillar savings & $\begin{array}{l}-0.002 \\
(0.006)\end{array}$ & $\begin{array}{l}-0.002 \\
(0.006)\end{array}$ \\
\hline $\operatorname{Income}(>50 q)$ & $\begin{array}{c}0.003 \\
(0.004)\end{array}$ & \\
\hline Income $(>50 \mathrm{q}) * 3^{r} d$ Pillar savings & $\begin{array}{l}-0.004 \\
(0.004)\end{array}$ & \\
\hline Income $(25-50 q)$ & & $\begin{array}{c}-0.006^{*} \\
(0.004)\end{array}$ \\
\hline Income $(50-75 q)$ & & $\begin{array}{c}0.001 \\
(0.004)\end{array}$ \\
\hline Income(75-100q) & & $\begin{array}{c}-0.0004 \\
(0.006)\end{array}$ \\
\hline Income $(25-50 \mathrm{q}) * 3^{r} d$ Pillar savings & & $\begin{array}{c}0.002 \\
(0.005)\end{array}$ \\
\hline Income $(50-75 q) * 3^{r} d$ Pillar savings yes & & $\begin{array}{l}-0.004 \\
(0.005)\end{array}$ \\
\hline Income $(75-100 \mathrm{q}) * 3^{r} d$ Pillar savings & & $\begin{array}{l}-0.005 \\
(0.007)\end{array}$ \\
\hline Constant & $\begin{array}{c}0.044^{* * *} \\
(0.010)\end{array}$ & $\begin{array}{c}0.046^{* * *} \\
(0.010)\end{array}$ \\
\hline Household Fixed Effects & $\mathrm{Y}$ & $\mathrm{Y}$ \\
\hline MS Region Fixed Effects & $\mathrm{N}$ & Y \\
\hline Observations & 26,543 & 26,543 \\
\hline $\mathrm{R}^{2}$ & 0.009 & 0.009 \\
\hline Adjusted $\mathrm{R}^{2}$ & 0.005 & 0.005 \\
\hline F Statistic & $\begin{array}{c}2.225^{* * *} \\
(\mathrm{df}=110 ; 26432)\end{array}$ & $\begin{array}{c}2.207^{* * *} \\
(\mathrm{df}=114 ; 26428)\end{array}$ \\
\hline
\end{tabular}

Note: $p<0.1 ;^{* *} p<0.05 ;{ }^{* * *} p<0.01$, standard errors are clustered at the household level 